\title{
Northern Mediterranean climate since the Middle Pleistocene: a 637 ka stable isotope record from Lake Ohrid (Albania/Macedonia)
}

\author{
Jack H. Lacey ${ }^{1,2}$, Melanie J. Leng ${ }^{1,2}$, Alexander Francke ${ }^{3}$, Hilary J. Sloane ${ }^{2}$, Antoni Milodowski ${ }^{4}$, Hendrik Vogel ${ }^{5}$, \\ Henrike Baumgarten $^{6}$, Giovanni Zanchetta ${ }^{7}$, and Bernd Wagner ${ }^{3}$ \\ ${ }^{1}$ Centre for Environmental Geochemistry, School of Geography, University of Nottingham, Nottingham, NG7 2RD, UK \\ ${ }^{2}$ NERC Isotope Geosciences Facilities, British Geological Survey, Keyworth, Nottingham, NG12 5GG, UK \\ ${ }^{3}$ Institute of Geology and Mineralogy, University of Cologne, 50674 Cologne, Germany \\ ${ }^{4}$ British Geological Survey, Keyworth, Nottingham, NG12 5GG, UK \\ ${ }^{5}$ Institute of Geological Sciences \& Oeschger Centre for Climate Change Research, University of Bern, \\ 3012 Bern, Switzerland \\ ${ }^{6}$ Leibniz Institute for Applied Geophysics, 30655 Hanover, Germany \\ ${ }^{7}$ Dipartimento di Scienze della Terra, University of Pisa, Pisa, Italy \\ Correspondence to: Jack H. Lacey (jackl@bgs.ac.uk)
}

Received: 28 July 2015 - Published in Biogeosciences Discuss.: 20 August 2015

Revised: 4 March 2016 - Accepted: 10 March 2016 - Published: 24 March 2016

\begin{abstract}
Lake Ohrid (Macedonia/Albania) is an ancient lake with unique biodiversity and a site of global significance for investigating the influence of climate, geological, and tectonic events on the generation of endemic populations. Here, we present oxygen $\left(\delta^{18} \mathrm{O}\right)$ and carbon $\left(\delta^{13} \mathrm{C}\right)$ isotope data from carbonate over the upper $243 \mathrm{~m}$ of a composite core profile recovered as part of the Scientific Collaboration on Past Speciation Conditions in Lake Ohrid (SCOP$\mathrm{SCO})$ project. The investigated sediment succession covers the past ca. $637 \mathrm{ka}$. Previous studies on short cores from the lake (up to $15 \mathrm{~m},<140 \mathrm{ka}$ ) have indicated the total inorganic carbon (TIC) content of sediments to be highly sensitive to climate change over the last glacial-interglacial cycle. Sediments corresponding to warmer periods contain abundant endogenic calcite; however, an overall low TIC content in glacial sediments is punctuated by discrete bands of early diagenetic authigenic siderite. Isotope measurements on endogenic calcite $\left(\delta^{18} \mathrm{O}_{\mathrm{c}}\right.$ and $\left.\delta^{13} \mathrm{C}_{\mathrm{c}}\right)$ reveal variations both between and within interglacials that suggest the lake has been subject to palaeoenvironmental change on orbital and millennial timescales. We also measured isotope ratios from authigenic siderite $\left(\delta^{18} \mathrm{O}_{\mathrm{s}}\right.$ and $\left.\delta^{13} \mathrm{C}_{\mathrm{s}}\right)$ and, with the oxygen isotope composition of calcite and siderite, reconstruct $\delta^{18} \mathrm{O}$ of lake water $\left(\delta^{18} \mathrm{O}_{\mathrm{lw}}\right)$ over the last $637 \mathrm{ka}$. Interglacials have
\end{abstract}

higher $\delta^{18} \mathrm{O}_{\mathrm{lw}}$ values when compared to glacial periods most likely due to changes in evaporation, summer temperature, the proportion of winter precipitation (snowfall), and inflow from adjacent Lake Prespa. The isotope stratigraphy suggests Lake Ohrid experienced a period of general stability from marine isotope stage (MIS) 15 to MIS 13, highlighting MIS 14 as a particularly warm glacial. Climate conditions became progressively wetter during MIS 11 and MIS 9. Interglacial periods after MIS 9 are characterised by increasingly evaporated and drier conditions through MIS 7, MIS 5, and the Holocene. Our results provide new evidence for long-term climate change in the northern Mediterranean region, which will form the basis to better understand the influence of major environmental events on biological evolution within Lake Ohrid.

\section{Introduction}

Global climate models indicate the Mediterranean to be a highly vulnerable area with respect to predicted future changes in temperature and precipitation regimes (Giorgi, 2006; Giannakopoulos et al., 2009), and the associated stress on water resources may have important socioeconomic im- 
pacts across the region (García-Ruiz et al., 2011). It is therefore vital to investigate the regional response to past climate fluctuations and improve our understanding of global climate dynamics as a prerequisite for establishing future scenarios (Leng et al., 2010a). Stable isotope ratios preserved in sedimentary lacustrine carbonates are a proxy for past climate and hydrological change (Leng and Marshall, 2004), and combinations of lake records can be used to assess the spatial coherence of isotope variations (Roberts et al., 2008). Although there are numerous stable isotope records from the Mediterranean, for example from marine sediment cores (Piva et al., 2008; Maiorano et al., 2013; Regattieri et al., 2014) and speleothems (Bar-Matthews et al., 2003; Antonioli et al., 2004), those from lacustrine carbonate typically are Late Glacial-Holocene in age (Dean et al., 2013; Francke et al., 2013) and only a limited number of extend beyond the Last Glacial (Frogley et al., 1999; Kwiecien et al., 2014; Giaccio et al., 2015; Regattieri et al., 2016).

Lake Ohrid, located on the Balkan Peninsula in southeastern Europe, is thought to be among the oldest extant lakes on Earth with a limnological age in excess of 1.2 million years (Wagner et al., 2014; Lindhorst et al., 2015). So-called ancient lakes are often associated with an outstanding degree of natural biodiversity, and Ohrid is one of only a few lakes worldwide to contain such a varied assemblage with over 300 endemic species (Albrecht and Wilke, 2008; Föller et al., 2015). Previous core sequences span the past 140000 years and proxies (e.g. geochemical, pollen, diatoms) indicate Lake Ohrid to be highly sensitive to both long- and short-term environmental change (Wagner et al., 2008, 2009, 2010; Vogel et al., 2010). Based on the potential for extended palaeoenvironmental reconstructions, the Scientific Collaboration on Past Speciation Conditions in Lake Ohrid (SCOPSCO) project was established within the framework of the International Continental scientific Drilling Program (ICDP). The principle aims of the SCOPSCO project are (1) to obtain precise information about the age and origin of the lake, (2) to unravel the regional seismotectonic history, (3) to obtain a continuous record containing information on Quaternary climate change and volcanic activity in the central northern Mediterranean region, and (4) to evaluate the influence of major geological events on evolution and the generation of the observed extraordinary degree of endemic biodiversity (see Wagner et al., 2014).

Existing records from Lake Ohrid have been analysed for the isotope composition of carbonate over the last glacialinterglacial cycle, including fine-grained calcite (endogenic) from bulk sediment (Leng et al., 2010a; Lacey et al., 2015) and benthic ostracods (Belmecheri et al., 2010). However, the current isotope data sets do not have the temporal range necessary to meet the primary research aims of the SCOPSCO project (Wagner et al., 2014). Here, we present new stable isotope data from carbonates (endogenic calcite and authigenic siderite) from SCOPSCO cores covering ca. $637 \mathrm{ka}$ (Baumgarten et al., 2015; Francke et al., 2016) and also reconstruct the oxygen isotope composition of lake water $\left(\delta^{18} \mathrm{O}_{\mathrm{lw}}\right)$. These data represent an extensive isotope stratigraphy covering multiple orbital cycles that provides valuable information on long-term palaeoenvironmental change between interglacial and glacial periods and on millennialscale variability within interglacial stages. The isotope data presented here will ultimately act as a reference record for climate change in the Mediterranean and across the Northern Hemisphere, provide a better understanding of the magnitude and timing of Late Quaternary climate oscillations, and deliver a robust framework to investigate SCOPSCO aims (3) and (4).

\section{General setting}

Lake Ohrid (Former Yugoslav Republic of Macedonia/Republic of Albania) is situated at $693 \mathrm{~m}$ above sea level (a.s.1.) and formed in a tectonic graben bounded by high mountain chains to the west and east (Fig. 1). The lake has a maximum length of $30.8 \mathrm{~km}$, a maximum width of $14.8 \mathrm{~km}$, an area of $358 \mathrm{~km}^{2}$, and a volume of $50.7 \mathrm{~km}^{3}$ (Stankovic, 1960; Popovska and Bonacci, 2007); the basin has a simple bath tub-shaped morphology with a maximum and average water depth of 293 and $150 \mathrm{~m}$ respectively (Lindhorst et al., 2015). There is a relatively small catchment area of $2600 \mathrm{~km}^{2}$, even accounting for input from neighbouring Lake Prespa, which delivers water through a network of karst aquifers thought to correspond to $53 \%$ of total water input (Matzinger et al., 2006a). The subterranean connection has been confirmed using tracer experiments (Anovski et al., 1991; Amataj et al., 2007) and feeds spring complexes mainly to the south-east of the lake (Eftimi and Zoto, 1997; Matzinger et al., 2006a). The remaining input comprises river inflow (24\%) and direct precipitation on the lake's surface $(23 \%)$. Water output is via the river Crim Drim on the northern margin (66\%) and by means of evaporation (34\%) (Matzinger et al., 2006b). Lake Ohrid has a hydraulic residence time of around 70 years and complete overturn is thought to occur approximately every 7 years (Hadzisce, 1966), which leads to de-stratification of the water column during deep convective winter mixing (Matzinger et al., 2006b).

Mediterranean climate is generally influenced by the subtropical anticyclone in summer and mid-latitude westerlies during winter, providing a complex and sensitive climatology at a major transition zone between temperate and arid domains (Lionello et al., 2012). This leads to precipitation seasonality controlled by the southward migration of the Intertropical Convergence Zone during winter, allowing the influence of westerlies to be established, and the development of cyclogenesis across the Mediterranean (Harding et al., 2009). Local orography produces climatic sub-zones with variable distributions of precipitation and temperature across the Mediterranean (Zanchetta et al., 2007), and the climate 

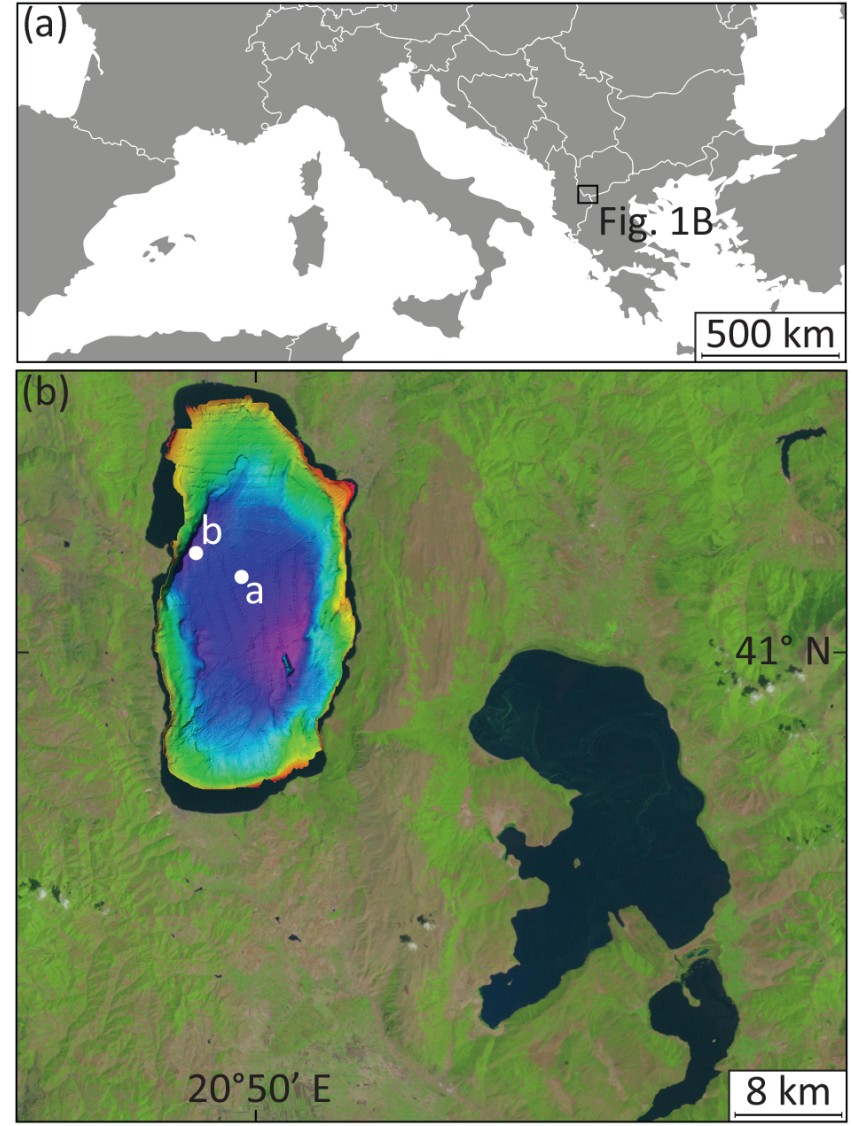

Figure 1. (a) Map of southern Europe and the northern Mediterranean showing the location of (b). (b) Landsat map of Lake Ohrid and Lake Prespa, showing Ohrid lake-floor morphology (Lindhorst et al., 2015) and indicating the locations of coring sites (a) DEEP 5045-1 and (b) Lini Co1262 (Wagner et al., 2012; Lacey et al., 2015).

of Lake Ohrid and its watershed is controlled by both subMediterranean and continental influences owing to its location in a deep basin sheltered by mountains and its proximity to the Adriatic Sea (Vogel et al., 2010; Panagiotopoulos et al., 2013). Today, air temperatures range between a minimum of $-6^{\circ} \mathrm{C}$ and a maximum of $+32^{\circ} \mathrm{C}$ and have an annual average of around $+10^{\circ} \mathrm{C}$ (Fig. 2; Popovska and Bonacci, 2007). Lake Ohrid surface water temperature remains between +6 and $+26^{\circ} \mathrm{C}$ and bottom water temperature is constant between +5 and $+6^{\circ} \mathrm{C}$ (Popovska and Bonacci, 2007). The catchment receives an average annual rainfall of around $900 \mathrm{~mm}$ and the prevailing northerly-southerly winds trace the Ohrid valley (Stankovic, 1960).

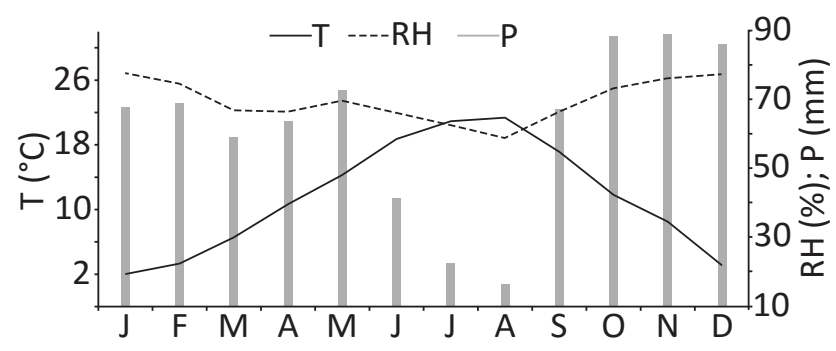

Figure 2. Recent climate data from the town of Ohrid (WMO station 135780: $41.1170^{\circ} \mathrm{N}, 20.8000^{\circ} \mathrm{E} ; 761 \mathrm{ma.s.1}$.) showing monthly averages over the period 2010-2014 for average temperature $(T)$, precipitation $(P)$, and relative humidity $(\mathrm{RH})$ (data available from WMO, 2015)

\section{Material and methods}

\subsection{Core recovery}

The ICDP SCOPSCO coring campaign of spring 2013 was a resounding success with over $2100 \mathrm{~m}$ of sediment recovered from four different sites; a full overview of coring locations, processes, and initial data is given by Wagner et al. (2014). To summarise, drill sites were selected based on hydro-acoustic and seismic surveys carried out between 2004 and 2008, which show the main target location to be in the thick undisturbed sediments of the central basin with an estimated continuous sedimentary fill of up to $680 \mathrm{~m}$. Coring at the "DEEP" site (5045-1; 41 $\left.02^{\prime} 57^{\prime \prime} \mathrm{N}, 020^{\circ} 42^{\prime} 54^{\prime \prime} \mathrm{E}\right)$ used the Deep Lake Drilling System (DLDS) operated by Drilling, Observation and Sampling of Earths Continental Crust (DOSECC) to reach a maximum sediment depth of $569 \mathrm{~m}$ below lake floor (m b.l.f.) and returned $1526 \mathrm{~m}$ of core material from six drill holes (95\% composite recovery; $99 \%$ for the upper $430 \mathrm{~m}$ ). The cores were subsequently processed and correlated at the University of Cologne to provide a composite profile for the DEEP site sequence, which currently extends down to $247.8 \mathrm{~m}$ core depth (described by Francke et al., 2016). Total inorganic carbon (TIC) data were measured by Francke et al. (2016) using a DIMATOC 100 carbon analyser (Dimatec Corp., Germany).

\subsection{Chronology}

The age model for the upper $247.8 \mathrm{~m}$ of the DEEP site sequence was established by (1) using tephrostratigraphical information (first-order tie points) and (2) tuning total organic carbon (TOC) and TOC/total nitrogen (TN) to trends in local daily insolation patterns (26 June at $41^{\circ} \mathrm{N}$; Laskar et al., 2004 ) and the winter season length (second-order tie points; cf. Francke et al., 2016). The tie points comprise 11 tephra layers, correlated to well-known Italian volcanic eruptions by geochemical fingerprint analysis (age and error is based on recalibration of $\mathrm{Ar} / \mathrm{Ar}$ ages from the literature by Leicher et al., 2015), and 30 tuning points. The tuning points are based 
on TOC and TOC / TN minima, which are observed to be coincident with inflection points in summer insolation and winter season length. For each TOC tuning point, an error of \pm 2000 years was included in the age-depth calculation to account for inaccuracies in the tuning process (Francke et al., 2016). Finally, the age model for the sediment cores was cross-evaluated with the age model of the borehole logging data (Baumgarten et al., 2015). The latter is based on tuning $\mathrm{K}$ concentration from downhole spectral gamma ray to LR04 and cyclostratigraphic analysis on gamma ray data. Chronological information and tie points are presented and discussed in detail in Francke et al. (2016); Leicher et al. (2015) and Baumgarten et al. (2015). The age model implies that the upper $247.8 \mathrm{~m}$ of the DEEP site composite profile represents the last ca. $637 \mathrm{ka}$, which broadly corresponds to marine isotope stage (MIS) 16 to MIS 1 (Lisiecki and Raymo, 2005; Railsback et al., 2015).

\subsection{Analytical work}

The DEEP site composite profile was sampled for oxygen and carbon isotope ratios $\left(\delta^{18} \mathrm{O}\right.$ and $\left.\delta^{13} \mathrm{C}\right)$ on carbonate at $16 \mathrm{~cm}$ intervals from the surface to $242.98 \mathrm{~m}$ throughout zones with a high carbonate content (up to $10 \%$ TIC; thought to represent interglacials). A previous record (Lini core Co1262; Lacey et al., 2015) provides the most extensive Holocene sequence recovered from Lake Ohrid to date, and so it is utilised in place of the uppermost sediments of the composite profile. The carbonate found within zones of high TIC predominantly consists of calcite. Idiomorphic calcite crystals and crystal clusters between 20 and $100 \mu \mathrm{m}$ have been reported from previous scanning electron microscopy investigations, which show the crystals to be dominantly $\mathrm{CaCO}_{3}$ (Wagner et al., 2008; Matter et al., 2010). The size and shape of the crystals are typical of endogenic precipitation (Leng et al., 2010b; Lézine et al., 2010), and although $\mathrm{CaCO}_{3}$ crystals recovered from sediment traps are generally pristine (Matter et al., 2010), those from core material are typically characterised by partial dissolution (Wagner et al., 2009).

Within zones of overall low TIC, intermittent spikes to higher TIC were also sampled and the constituent carbonate species investigated using X-ray diffraction (XRD), as $\mathrm{X}$-ray fluorescence (XRF) showed the spikes were high in $\mathrm{Fe}$ and Mn (Francke et al., 2016). XRD was conducted on a PANalytical X'Pert Pro powder diffractometer, with Cobalt $\mathrm{K} \alpha_{1}$ radiation over the scan range $4.5-85^{\circ} 2 \theta$ and a step size of $2.06^{\circ} 2 \theta \mathrm{min}^{-1}$. Phase identification was conducted using PANalytical HighScore Plus version 4.0 analytical software interfaced with the latest version of the International Centre for Diffraction Data (ICDD) database. The XRD analysis showed the carbonate in the samples to consist of siderite, which was confirmed using energy-dispersive X-ray spectroscopy (EDX) on epoxy resin-embedded thin sections.
Relative concentration changes of the carbonate phases (calcite and siderite) were determined at $32 \mathrm{~cm}$ intervals from the surface to a correlated depth of $247.8 \mathrm{~m}$ using Fourier transform infrared spectroscopy (FTIR). For FTIR analysis, $0.011 \pm 0.0001 \mathrm{~g}$ of each sample was mixed with $0.5 \pm 0.0001 \mathrm{~g}$ of oven-dried spectroscopic-grade potassium bromide (KBr) (Uvasol ${ }^{\circledR}$, Merck Corp.) and subsequently homogenised using a mortar and pestle. A Bruker Vertex 70 equipped with an MCT (mercury-cadmium-telluride) detector, a KBr beam splitter, and an HTS-XT accessory unit (multi-sampler) was used for the measurement. Each sample was scanned 64 times at a resolution of $4 \mathrm{~cm}^{-1}$ (reciprocal centimetres) for the wave number range from 3750 to $520 \mathrm{~cm}^{-1}$ in diffuse reflectance mode. FTIR analysis was performed at the Institute of Geological Sciences, University of Bern, Switzerland. Linear baseline correction was applied to normalise the recorded FTIR spectra and to remove baseline shifts and tilts by setting two points of the recorded spectrum to 0 ( 3750 and $2210-2200 \mathrm{~cm}^{-1}$ ). Peak areas diagnostic for bending vibrations of the carbonate ion in calcite $\left(707-719 \mathrm{~cm}^{-1}\right)$ and siderite $\left(854-867 \mathrm{~cm}^{-1}\right)$ and representative for their relative abundance (White, 1974; Chukanov, 2014) were integrated using the OPUS (Bruker Corp.) software package.

For the isotope analysis, approximately $250 \mathrm{mg}$ (calcite) or $1000 \mathrm{mg}$ (siderite) of sample was disaggregated in $5 \%$ sodium hypochlorite solution for $24 \mathrm{~h}$ to oxidise reactive organic material, then washed in deionised water to neutral $\mathrm{pH}$, dried at $40^{\circ} \mathrm{C}$ and ground to a fine powder. To evolve $\mathrm{CO}_{2}$ for isotope analysis, calcite-bearing samples were reacted overnight inside a vacuum with anhydrous phosphoric acid at a constant $25^{\circ} \mathrm{C}$, and siderite-bearing samples were reacted with anhydrous phosphoric acid within a vacuum for $96 \mathrm{~h}$ at $100^{\circ} \mathrm{C}$. For both types of sample, $\mathrm{CO}_{2}$ was cryogenically separated from water vapour under vacuum and analysed using a VG Optima dual inlet mass spectrometer. The mineral-gas fractionation factor used for calcite was 1.01025 and for siderite was 1.00881 (Rosenbaum and Sheppard, 1986). The oxygen and carbon isotope composition of calcite $\left(\delta^{18} \mathrm{O}_{\mathrm{c}}\right.$ and $\left.\delta^{13} \mathrm{C}_{\mathrm{c}}\right)$ and siderite $\left(\delta^{18} \mathrm{O}_{\mathrm{s}}\right.$ and $\left.\delta^{13} \mathrm{C}_{\mathrm{s}}\right)$ are reported as per mille (\%o) deviations of the isotope ratios $\left({ }^{18} \mathrm{O} /{ }^{16} \mathrm{O}\right.$ and $\left.{ }^{13} \mathrm{C} /{ }^{12} \mathrm{C}\right)$ calculated to the VPDB scale. Within-run laboratory standards were utilised for which analytical reproducibility was $<0.1 \%$ for $\delta^{18} \mathrm{O}$ and $\delta^{13} \mathrm{C}$.

\section{Results}

Isotope data from core 5045-1 are shown in Fig. 3. Calcite is found in zones corresponding to interglacial/interstadial periods characterised by high TIC (odd-numbered MIS) and siderite is present in glacial/stadial periods (even-numbered MIS; Francke et al., 2016). For calcite, over the whole record $\delta^{18} \mathrm{O}_{\mathrm{c}}=-5.3 \pm 0.8 \%$ o $(1 \sigma, n=924)$ and $\delta^{13} \mathrm{C}_{\mathrm{c}}+0.4 \pm$ $0.6 \%$ o $(1 \sigma, n=924)$. The sediments corresponding to MIS 
15 and 13 have consistent $\delta^{18} \mathrm{O}_{\mathrm{c}}$ (mean $=-5.5 \pm 0.7 \%$; $1 \sigma$, $n=294)$ and $\delta^{13} \mathrm{C}_{\mathrm{c}}($ mean $=+0.6 \pm 0.5 \%$; $1 \sigma, n=294)$. TIC remains relatively high through glacial MIS 14 and $\delta^{18} \mathrm{O}_{\mathrm{c}}$ is consistent with the bounding MIS values; however, $\delta^{13} \mathrm{C}_{\mathrm{c}}$ shows a trend to higher values. Minimum $\delta^{18} \mathrm{O}_{\mathrm{c}}$ for the whole record $(-7.6 \%$ ) occurs at ca. $378 \mathrm{ka}$ during MIS 11 (mean $\delta^{18} \mathrm{O}_{\mathrm{c}}=-5.5 \pm 0.9 \%$; $1 \sigma, n=75$ ), and $\delta^{13} \mathrm{C}_{\mathrm{c}}$ is relatively low with stable values (mean $\delta^{13} \mathrm{C}_{\mathrm{c}}=0.2 \pm 0.4 \%$; $1 \sigma, n=75)$. MIS 9 sediments have the lowest mean $\delta^{18} \mathrm{O}_{\mathrm{c}}$ of the record $(-6.0 \pm 0.8 \% ; 1 \sigma, n=87)$ and mean $\delta^{13} \mathrm{C}_{\mathrm{c}}$ $(0.4 \pm 0.6 \% ; 1 \sigma, n=87)$ is similar to previous warm stages. Subsequently, the lowest $\delta^{13} \mathrm{C}_{\mathrm{c}}$ of the record are observed between ca. 219 and $216 \mathrm{ka}$ in MIS 7 and $\delta^{18} \mathrm{O}_{\mathrm{c}}$ $(-5.5 \pm 0.6 \% ; 1 \sigma, n=73)$ is comparable to average $\delta^{18} \mathrm{O}_{\mathrm{c}}$ through MIS 15-13. MIS 5 contains the highest mean $\delta^{18} \mathrm{O}_{\mathrm{c}}$ $(-4.6 \pm 0.8 \% ; 1 \sigma, n=104)$, similar to $\delta^{18} \mathrm{O}_{\mathrm{c}}$ observed during the Holocene $(-4.9 \pm 0.7 \%, 1 \sigma, n=273$; Lacey et al., 2015), and shows high $\delta^{13} \mathrm{C}_{\mathrm{c}}$ (mean $=0.6 \pm 0.7 \%$; $1 \sigma$, $n=104)$. Siderite is found predominantly in areas of negligible TIC (glacial/stadial periods), with an increasing abundance in the upper core (after ca. $350 \mathrm{ka}$; Fig. 3). Overall, mean $\delta^{18} \mathrm{O}_{\mathrm{s}}=-2.2 \pm 0.8 \%$ o $(1 \sigma, n=22)$ and mean $\delta^{13} \mathrm{C}_{\mathrm{s}}=$ $+12.3 \pm 0.5 \%$ o $(1 \sigma, n=22)$. The sediments corresponding to MIS 10 have the highest $\delta^{18} \mathrm{O}_{\mathrm{s}}$ values, and the lowest $\delta^{18} \mathrm{O}_{\mathrm{s}}$ are observed during MIS 3 (however, given the low resolution of the siderite isotope data, variability between glacial stages cannot be thoroughly assessed at present).

\section{Discussion}

\subsection{Modern isotope data}

Understanding how the isotope composition of contemporary lake water relates to the measured signal from a mineral precipitate is fundamental in resolving the past systematics of hydroclimate variation from lacustrine records (Leng and Marshall, 2004). The isotope composition of lake water $\left(\delta^{18} \mathrm{O}_{\mathrm{lw}}\right)$ from Ohrid and Prespa, as well as spring inflows, have been previously investigated (water samples collected 1984-2011, summarised in Fig. 4; Eftimi and Zoto, 1997; Anovski et al., 2001; Matzinger et al., 2006a; Leng et al., 2010a, 2013). Modern waters from Lake Ohrid fall on a local evaporation line (LEL) away from the local meteoric water line (LMWL) inferring that they have undergone kinetic fractionation (average $\delta^{18} \mathrm{O}_{\mathrm{lw}}=-3.5 \%$; Leng and Marshall, 2004). Lake Prespa has a reduced surface area to volume ratio in comparison to Ohrid and is highly sensitive to seasonal variations in moisture balance (Popovska and Bonacci, 2007; Leng et al., 2010a); hence its waters fall higher on the LEL (average $\delta^{18} \mathrm{O}_{\mathrm{lw}}=-1.5 \%$ ). The initial water composition at the LMWL-LEL intersect suggests that both lakes are principally recharged from meteoric water, assumed to be similar to the mean annual isotope composition of precipitation $\left(\delta^{18} \mathrm{O}_{\mathrm{p}}\right)$ across the catchment $\left(\delta^{18} \mathrm{O}_{\mathrm{p}}=-10.2 \%\right.$; Anovski, 2001), which falls close to the average value for precipitation-fed spring waters $(-10.1 \%$ ). The spring complexes are split between those with lower $\delta^{18} \mathrm{O}$ (fed predominantly by isotopically depleted winter precipitation) and those with higher $\delta^{18} \mathrm{O}$ (having an evaporated component). Mixing analysis at spring complexes primarily to the south-east of Ohrid indicates they receive up to $53 \%$ of their incoming water budget from Prespa (Anovski et al., 2001; Eftimi et al., 2001; Matzinger et al., 2006a). Springs deliver around half of total inflow to Lake Ohrid, and therefore a large proportion of water input will be seasonally variable as it is derived from Lake Prespa (lower $\delta^{18} \mathrm{O}_{\mathrm{lw}}$ in winter and higher during summer). Contemporary waters from Lake Ohrid show uniform $\delta^{18} \mathrm{O}_{\mathrm{lw}}$ values over the ca. 30-year sampling period, signifying that seasonal variations in the water contribution from Lake Prespa have a negligible overall effect, most probably due to Ohrid's large volume and long lake water residence time (Leng et al., 2010a). This suggests that, in combination with modern lake water that has higher $\delta^{18} \mathrm{O}$ than local meteoric water, changes in the isotope composition of lake water $\left(\delta^{18} \mathrm{O}_{\mathrm{lw}}\right)$ are principally driven by regional water balance and most likely represent lower frequency changes in climate.

\subsection{Late Glacial to Holocene isotope data}

A $10 \mathrm{~m}$ core (Co1262), recovered from the western margin of Lake Ohrid at the "Lini" drill site (Fig. 1), has been analysed for $\delta^{18} \mathrm{O}_{\mathrm{c}}$ and $\delta^{13} \mathrm{C}_{\mathrm{c}}$ at high resolution over the Late Glacial to Holocene (Lacey et al., 2015); the study is utilised here as a recent comparison for the longer-term reconstruction in combination with the modern water isotope data. Lacey et al. (2015) highlighted the significance of Lake Ohrid as a sensitive recorder of climate change and confirmed that Ohrid responds to regional changes in water balance over the Holocene. Core Co1262 has $\delta^{18} \mathrm{O}_{c}$ ranging between -6.5 and $-2.1 \%$, being higher following the Late Glacial to Holocene transition, reaching a minimum between approximately 9 and $7 \mathrm{ka}$, and subsequently undergoing a step-wise increase to present-day values (Fig. 5). This pattern of $\delta^{18} \mathrm{O}_{\mathrm{c}}$ variability is similar to other lake sediment sequences from Greece (Lake Pamvotis; Frogley et al., 2001) and Turkey (Lake Acıgöl; Roberts et al., 2001), as well as in speleothem records from Israel (Soreq Cave; Bar-Matthews et al., 1999). A period of sustained moisture availability above that of present-day values is recorded between 8 and $6.5 \mathrm{ka}$ from Lake Acıgöl (Roberts et al., 2001), which is likewise identified at Lake Pamvotis where higher lake levels are inferred by a reduction in the quantity of shallow water ostracod taxa (Frogley et al., 2001). The Soreq Cave speleothem record indicates a greater annual number of heavy rainstorms throughout the period 10 to $7 \mathrm{ka}$, with rainfall estimated to have been up to twice that of present day (Bar-Matthews et al., 1997), and similarly early Holocene rainfall is calculated to have increased by around $20 \%$ in central Anatolia (Jones 


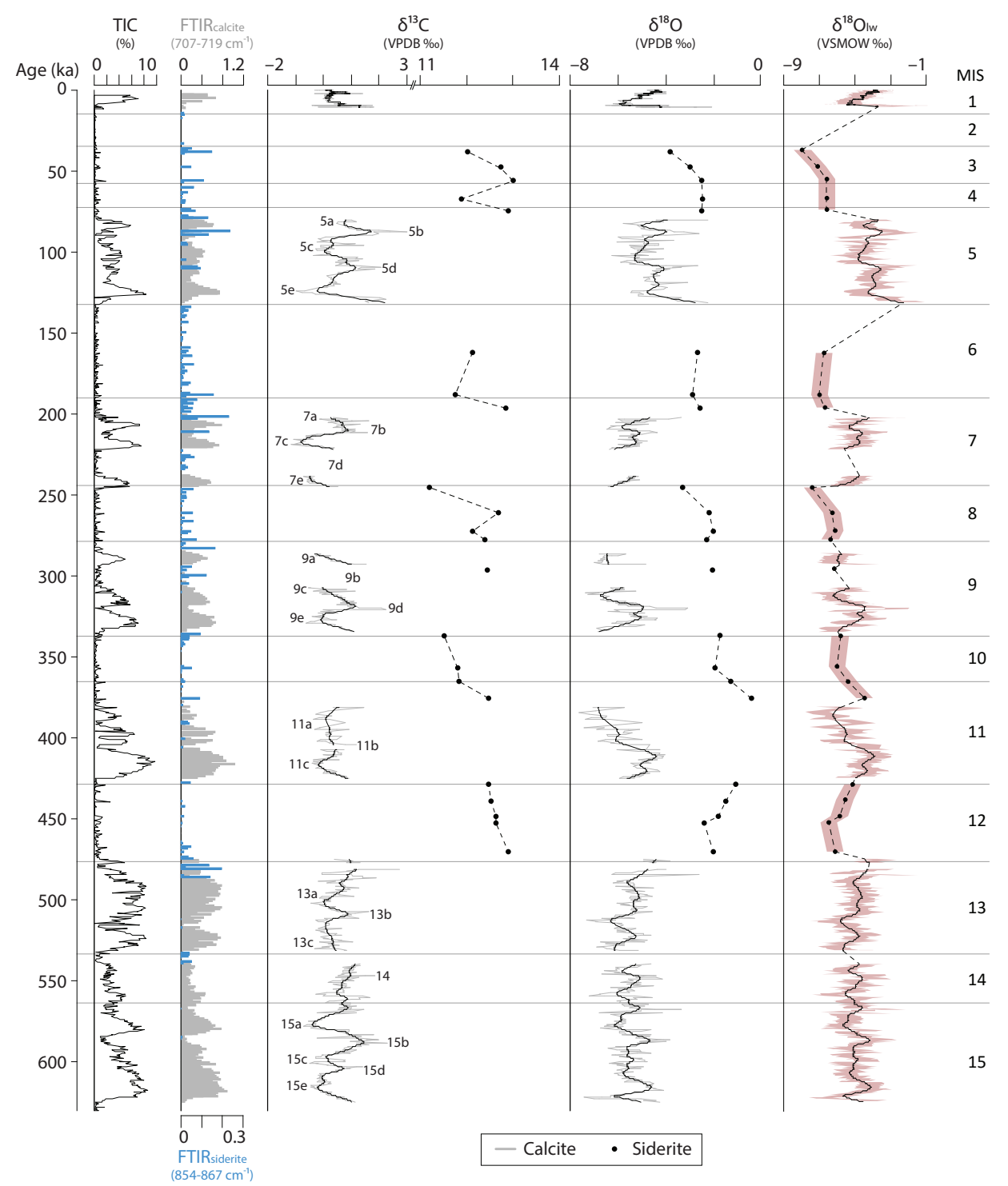

Figure 3. Isotope results from calcite $\left(\delta^{18} \mathrm{O}_{\mathrm{c}}, \delta^{13} \mathrm{C}_{\mathrm{c}}\right)$, siderite $\left(\delta^{18} \mathrm{O}_{\mathrm{s}}, \delta^{13} \mathrm{C}_{\mathrm{s}}\right)$, and calculated lake water $\left(\delta^{18} \mathrm{O}_{\mathrm{lw}}\right)$ from Lake Ohrid, also showing TIC (Francke et al., 2016), the Holocene Co1262 calibration data set $\left(\delta^{18} \mathrm{O}_{\mathrm{c}}, \delta^{13} \mathrm{C}_{\mathrm{c}}\right.$; Lacey et al., 2015), and MIS stratigraphy (Railsback et al., 2015). FTIR results are shown for calcite (grey bars; calcite area $=707-719 \mathrm{~cm}^{-1}$ ) and siderite (blue bars; siderite area $\left.=854-867 \mathrm{~cm}^{-1}\right)$. Calcite data are given as raw (grey line) and lowess as smooth ( $\mathrm{span}=0.02$; black line); siderite data are presented as individual points (black dots). For calculation of $\delta^{18} \mathrm{O}_{\mathrm{lw}},+18^{\circ} \mathrm{C}$ was assumed for calcite data (red shaded area $= \pm 3{ }^{\circ} \mathrm{C}$ ) and $+6^{\circ} \mathrm{C}$ for siderite data (red shaded area $= \pm 2{ }^{\circ} \mathrm{C}$ ); see text for further detail.

et al., 2007). A wetter early Holocene is suggested by several other central-eastern Mediterranean records, such as that from Lake Pergusa (Zanchetta et al., 2007), Lake Van (Wick et al., 2003), Lake Zeribar (Stevens et al., 2001), and Lake Göhlisar (Eastwood et al., 2007). The transition to drier climate conditions in the late Holocene is reflected across these records as a progressive shift to higher $\delta^{18} \mathrm{O}_{\mathrm{c}}$. Therefore, the Holocene calibration data set confirms that Lake Ohrid $\delta^{18} \mathrm{O}_{\mathrm{c}}$ is primarily driven by millennial-scale changes in regional water balance.

\subsection{SCOPSCO DEEP site isotope data}

\subsubsection{Oxygen isotope composition of calcite}

$\delta^{18} \mathrm{O}_{\mathrm{c}}$ is dependent on $\delta^{18} \mathrm{O}_{\mathrm{lw}}$ and the temperature of lake water at the time of mineral precipitation, assuming equilibrium conditions (Leng and Marshall, 2004). Sediment trap data from Lake Ohrid show that calcite precipitation is seasonally induced, with up to 3 times more TIC formed during summer months in comparison to winter months (Matzinger et al., 2007). The precipitation of calcite is thought to be 


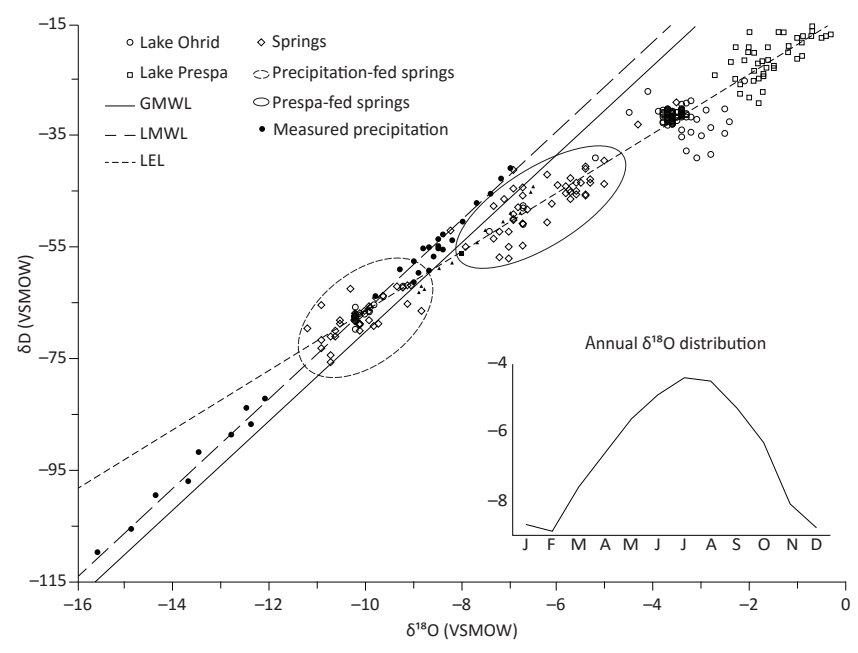

Figure 4. Modern isotope composition $\left(\delta^{18} \mathrm{O}\right.$ and $\left.\delta \mathrm{D}\right)$ of waters from lakes Ohrid and Prespa, springs, and local rainfall (Anovski et al., 1980, 1991, 2001; Eftimi and Zoto, 1997; Matzinger et al., 2006a; Jordanoska et al., 2010; Leng et al., 2010a). The Global Meteoric Water Line (GMWL; Craig, 1961), local meteoric water line (LMWL; Anovski et al., 1991; Eftimi and Zoto, 1997), and calculated local evaporation line (LEL) are given. The annual distribution of $\delta^{18} \mathrm{O}$ was calculated using the Online Isotopes in Precipitation Calculator (OIPC; Bowen et al., 2005; Bowen, 2015).

associated with increased temperatures and the photosynthetic removal of $\mathrm{CO}_{2}$ within the epilimnion, providing there is sufficient supply of calcium $\left(\mathrm{Ca}^{2+}\right)$ and bicarbonate $\left(\mathrm{HCO}_{3}^{-}\right)$ions, which are mainly sourced from spring inflows (Matzinger et al., 2006a). The production of phytoplankton in the lake reaches a maximum between June and August, during which the temperature of the main productivity zone ranges between approximately 12 and $22^{\circ} \mathrm{C}$ (Stankovic, 1960). If the average temperature of the photic zone during summer months is approximately $18{ }^{\circ} \mathrm{C}$, and we take the average modern $\delta^{18} \mathrm{O}_{\mathrm{lw}}$ of $-3.5 \%$ (Fig. 4), the calculated $\delta^{18} \mathrm{O}_{\mathrm{c}}$ of contemporary calcite precipitation should be approximately $-4.0 \%$, using the equation of O'Neil et al. (1969), or $-4.4 \%$, using the Leng and Marshall (2004) expression of Kim and O'Neil (1997). This is similar to the average $\delta^{18} \mathrm{O}_{\mathrm{c}}$ through the Holocene $(-4.9 \%$ ) and to the most recent measurement of $\delta^{18} \mathrm{O}_{\mathrm{c}}(-4.5 \%$ ) from core Co1262 (Lacey et al., 2015), suggesting that $\delta^{18} \mathrm{O}_{\mathrm{c}}$ most likely corresponds to summer lake water conditions.

Calcite may comprise up to $80 \%$ of the total sediment composition (assuming TIC mainly represents $\mathrm{CaCO}_{3}$; Wagner et al., 2008), with only a minor biogenic component $(<0.1 \%)$ and limited terrigenous contribution (Lézine et al., 2010). As Lake Ohrid is located within a karst catchment, a proportion of the carbonate could be of detrital origin, which commonly has a different isotope composition to the endogenic fraction (Leng et al., 2010b). The catchment geology has variable $\delta^{18} \mathrm{O}$ (-9.7 to $-2.6 \%$; Leng et al., 2010a); how-

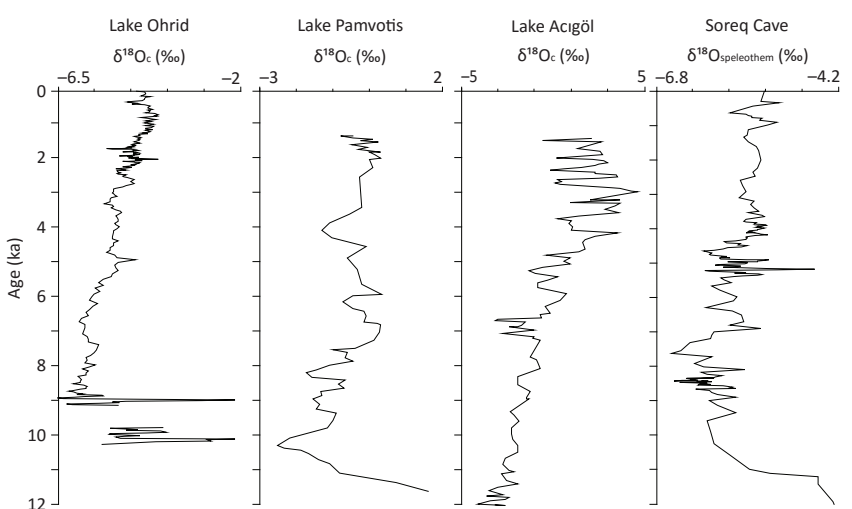

Figure 5. Comparison between the high-resolution Holocene $\delta^{18} \mathrm{O}_{\mathrm{c}}$ calibration data set from Lake Ohrid Lini core Co1262 (Lacey et al., 2015) and $\delta^{18} \mathrm{O}$ from other regional records, including Lake Pamvotis, Greece (Frogley et al., 2001), Lake Acıgöl, Turkey (Roberts et al., 2001), and Soreq Cave, Israel (Bar-Matthews et al., 1999).

ever, previous investigations on sediment trap and core material have shown that the calcite crystals have morphological characteristics (for example size and shape) typical of an endogenic origin (Lézine et al., 2010; Matter et al., 2010).

The modern isotope data from Lake Ohrid indicate a clear evaporative disparity between the isotope composition of lake water and that from meteoric and groundwater sources (Fig. 4). The calcite precipitated from a hypothetical, exclusively meteoric, water source would have $\delta^{18} \mathrm{O}_{\mathrm{c}}=-10.6 \%$ (using the mean summer lake water temperature of $+18^{\circ} \mathrm{C}$ and inflow $\delta^{18} \mathrm{O}$ of $-10.1 \%$ ). Similarly low $\delta^{18} \mathrm{O}_{c}$ is not observed in any isotope data from Lake Ohrid to date, including core catcher data covering the entire 1.2 Ma sediment sequence (Wagner et al., 2014), which indicates that lake water has always been subject to a varying extent of evaporative fractionation. This suggests that $\delta^{18} \mathrm{O}_{\mathrm{lw}}$ is primarily influenced by long-term changes in the precipitation/evaporation ratio $(P / E)$. Although temperature changes will influence $\delta^{18} \mathrm{O}_{\mathrm{lw}}$ values, the effect is reported to be roughly $+0.2 \% 0^{\circ} \mathrm{C}^{-1}$ for the central Mediterranean region (Bard et al., 2002), which is quantitatively compensated for by the equilibrium isotope fractionation between carbonate and water $\left(-0.2 \%{ }^{\circ} \mathrm{C}^{-1}\right.$; Leng and Marshall, 2004).

The $\delta^{18} \mathrm{O}_{\mathrm{c}}$ data from calcite in Lake Ohrid are largely restricted to the interglacial (or interstadial) periods. Interglacial sediments are characterised by concomitant increases in both TIC and TOC (Francke et al., 2016), suggested to be the result of enhanced primary productivity associated with a warmer climate (Wagner et al., 2010). Calcite precipitation is favoured by elevated temperatures during interglacials, which drives higher evaporation rates, thereby concentrating $\mathrm{Ca}^{2+}$ and $\mathrm{HCO}_{3}^{-}$ions. Further, elevated catchment soil activity and temperature will enhance the dissolution of 


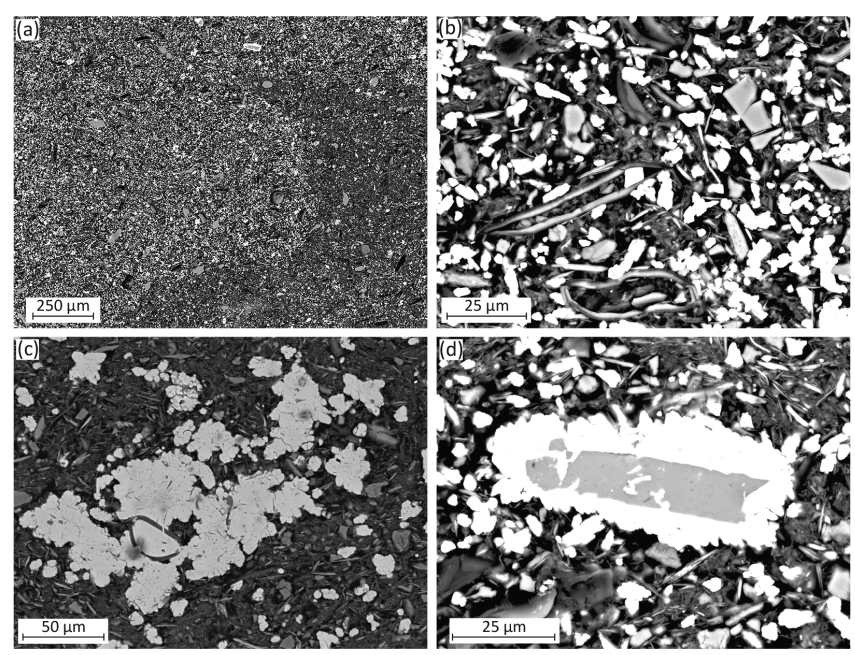

Figure 6. Backscatter scanning electron microscopy images of glacial sediment thin sections, showing (a) areas of high (brighter) and low (darker) siderite concentration in "burrow-like" structure, (b) areas of high siderite concentration (white euhedral crystals) in an open-packed matrix (note: central diatom appears split by siderite crystal), (c) individual siderite crystals amalgamating to form a larger siderite crystal cluster, and (d) siderite overgrowth fringing a rare detrital dolomite grain.

carbonate rocks leading to a greater concentration of dissolved ions in karst spring water. Warmer surface waters also lower the calcite saturation threshold (Lézine et al., 2010). Conversely, glacial sediments typically have low TIC and TOC that are inversely correlated with $\mathrm{K}$ and Ti concentrations, indicating low productivity and increased clastic input (Vogel et al., 2010). Lower temperatures during glacial periods would lead to a more oxygenated water column through increased vertical mixing and more frequent complete deep convective overturn. Enhanced levels of mixing breaks down water column stratification and associated oxygenation of the water column increases the rate of aerobic decomposition of organic matter, releasing $\mathrm{CO}_{2}$ that reduces $\mathrm{pH}$ levels and increases calcite dissolution (Vogel et al., 2010). Following extensive organic matter degradation the $\mathrm{C} / \mathrm{N}$ ratio of sediments may be significantly reduced, as observed in the DEEP site cores (Francke et al., 2016) and in previous cores from Lake Ohrid where during the Last Glacial C / N values were typically very low (4-5) compared to higher values (8-12) in both the Holocene and MIS 5 (Wagner et al., 2009; Leng et al., 2010a). Catchment permafrost may have also been prevalent in glacial periods, limiting the supply of $\mathrm{Ca}^{2+}$ and $\mathrm{HCO}_{3}^{-}$ions to the lake by reducing the volume of karstic spring inflow (Belmecheri et al., 2009), which is supported by pollen-inferred mean annual temperatures during the last glacial period of between -3 and $+1^{\circ} \mathrm{C}$ (Bordon et al., 2009). Although there is no (or limited) calcite in the glacials, previous work on Lake Ohrid has shown spikes in TIC during MIS 2-3 (Wagner et al., 2010), and similar in- creases in glacial TIC are observed throughout the 5045-1 composite profile (Francke et al., 2016). These TIC spikes are most likely analogous to those found in Lake Prespa glacial sediments during MIS 4-2, which comprise siderite (Leng et al., 2013).

\subsubsection{Oxygen isotope composition of siderite}

Thin sections from discrete higher-TIC glacial intervals reveal individual siderite crystals $(<5 \mu \mathrm{m})$ and siderite crystal clusters $(50-100 \mu \mathrm{m})$ nucleating within an uncompacted clay matrix (Fig. 6). The distribution of siderite within each thin section is variable; a higher concentration of siderite crystals is contained within burrow-like structures that impart a mottled texture to the sediment. Occasional dolomite grains, large $(>20 \mu \mathrm{m})$ and distinct from the fine clay matrix, are fringed by $5 \mu \mathrm{m}$ grains of siderite. The dolomite crystals are thought to be detrital as they are larger than the individual siderite grains and have irregular margins. Siderite comprises the principal carbonate component in these horizons, and apart from the occasional dolomite crystals, no other type of carbonate was observed. Individual siderite crystals appear to predominantly form within the open framework of the clay matrix, which suggests they precipitated in situ within the available pore space. The siderite is therefore most likely to be early diagenetic and formed before compaction within the sediment. Discrete horizons enriched in Fe have been previously observed in Lake Ohrid (Vogel et al., 2010), neighbouring Lake Prespa (Wagner et al., 2010; Leng et al., 2013), and in other ancient lakes, such as Lake Baikal (Granina et al., 2004), where the formation of Fe-enriched layers up to approximately $25 \mathrm{~cm}$ below the sediment-water interface is thought to be related to bottom water redox conditions and significant changes in sedimentation regime. Assuming the siderite is formed in superficial sediments during the initial stages of diagenesis, like calcite, its isotope composition can be used as an indicator of depositional environment (Mozley and Wersin, 1992).

\subsubsection{Comparison of the oxygen isotope composition of calcite and siderite}

To enable comparison between $\delta^{18} \mathrm{O}_{\mathrm{c}}$ and $\delta^{18} \mathrm{O}_{\mathrm{s}}$, we convert both to $\delta^{18} \mathrm{O}_{\mathrm{lw}}$ using specific mineral fractionation equations and different estimates of temperature. For calcite data we use the equation of O'Neil et al. (1969) and a precipitation temperature of $+18^{\circ} \mathrm{C}\left( \pm 3^{\circ} \mathrm{C}\right)$ to represent average summer conditions within the photic zone during the period of maximum phytoplankton activity. For siderite data we use the equation of Zhang et al. (2001), which is considered robust for defining equilibrium precipitation at lower temperatures (Ludvigson et al., 2013), and assume a bottom water temperature of $+6^{\circ} \mathrm{C}\left( \pm 2{ }^{\circ} \mathrm{C}\right.$; Stankovic, 1960). The calculated $\delta^{18} \mathrm{O}_{\mathrm{lw}}$ is given in Fig. 3 and the averages for each MIS are compared to those of $\delta^{13} \mathrm{C}_{\mathrm{c}}$ and $\delta^{13} \mathrm{C}_{\mathrm{s}}$ in Fig. 7a. 
The calculated $\delta^{18} \mathrm{O}_{\text {lw }}$ from glacial siderite is generally lower compared that from calcite (higher $\delta^{18} \mathrm{O}_{\mathrm{lw}}$ ) during warmer interglacial periods (Fig. 7). Although siderite horizons probably represent distinct rapid and recurrent events in Lake Ohrid (Vogel et al., 2010), overall lower $\delta^{18} \mathrm{O}_{\mathrm{lw}}$ may nevertheless be expected through glacial periods due to reduced lake water evaporation as a result of decreased temperatures. Jones et al. (2007) calculated evaporation rates at Eski Acıgöl in central Turkey and showed that glacial evaporation was around 3 times lower compared to that of the Late Holocene $\left(0.4 \mathrm{~m} \mathrm{yr}^{-1}\right.$ vs. $\left.1.1 \mathrm{~m} \mathrm{yr}^{-1}\right)$. If a similar calculation is conducted for Lake Ohrid, glacial evaporation may have been over 4 times lower than during the present interglacial $\left(0.4 \mathrm{~m} \mathrm{yr}^{-1}\right.$ vs. $\left.1.8 \mathrm{~m} \mathrm{yr}^{-1}\right)$, after Jones et al. (2007) using the equation of Linacre (1992). Higher evaporation rates are typically associated with closed lake basins and covariance between $\delta^{18} \mathrm{O}$ and $\delta^{13} \mathrm{C}$ (Talbot, 1990; Li and $\mathrm{Ku}, 1997$ ), which is observed in the Lake Ohrid data as interglacial $\delta^{18} \mathrm{O}_{\mathrm{lw}}$ from calcite has a moderate covariance $(r=0.30$; Fig. 7b), corroborating that interglacial periods were characterised by higher evaporation. As rates of evaporation reduce during colder intervals, the influence of other controlling factors, such as $\delta^{18} \mathrm{O}_{\mathrm{p}}$, may have had a greater importance in determining $\delta^{18} \mathrm{O}_{\mathrm{lw}}$ during glacial periods.

During colder intervals, $\delta^{18} \mathrm{O}_{\mathrm{p}}$ would have been lower as a direct correlation exists between annual precipitation and temperature of $+0.6 \% 0^{\circ} \mathrm{C}^{-1}$ at mid-high latitudes (Dansgaard, 1964) and $+0.2 \%{ }^{\circ} \mathrm{C}^{-1}$ in the central Mediterranean (Bard et al., 2002). If a mean annual temperature difference of up to $9^{\circ} \mathrm{C}$ is assumed between interglacial and glacial periods, based on pollen-inferred temperature data from nearby Lake Maliq (Bordon et al., 2009), $\delta^{18} \mathrm{O}_{\mathrm{p}}$ may have decreased by between -5.4 and $-1.8 \%$ in glacial periods. When considering interglacial-glacial timescales, changes to the oxygen isotope composition of seawater may also influence $\delta^{18} \mathrm{O}_{\mathrm{p}}$. The isotope composition of mean global seawater is reported to be $1.0 \%$ higher during the last glacial due to the expansion of global ice volume (Schrag et al., 2002) and up to $1.2 \%$ in the Mediterranean due to local evaporative enrichment (Paul et al., 2001). Therefore, the net effect of temperature and source changes during glacial periods results in lower $\delta^{18} \mathrm{O}_{\mathrm{p}}$.

In addition to more regional effects on $\delta^{18} \mathrm{O}_{\mathrm{lw}}$, local influences may also contribute to lower isotope values through glacial periods. Today, a significant proportion of winter precipitation occurs as snowfall at higher altitudes in the OhridPrespa catchment, which is ultimately transferred to the lakes during spring when temperatures remain high enough for the snow to melt (Hollis and Stevenson, 1997; Popovska and Bonacci, 2007). Average winter temperatures at present are around $2{ }^{\circ} \mathrm{C}$ (Stankovic, 1960); however, winter temperatures would have been considerably reduced during glacial periods and temperatures during summer months may also have been lower (Bordon et al., 2009). If lower temperatures persisted throughout much of the year, a higher proportion
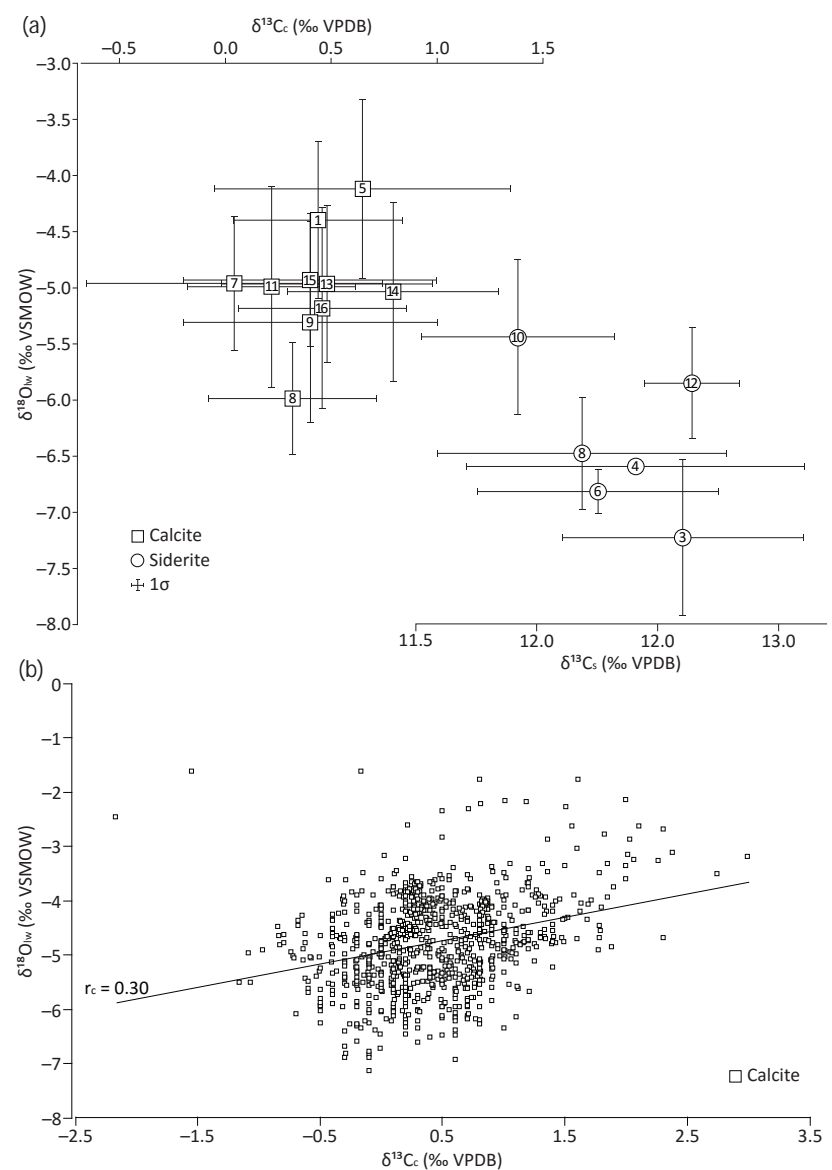

Figure 7. (a) $\delta^{18} \mathrm{O}_{\mathrm{lw}}-\delta^{13} \mathrm{C}_{\mathrm{c}}$ and $\delta^{18} \mathrm{O}_{\mathrm{lw}}-\delta^{13} \mathrm{C}_{\mathrm{s}}$ cross-plot showing the average and standard deviation $(1 \sigma)$ of each MIS (numbered centre points) for both calcite and siderite data; (b) $\delta{ }^{18} \mathrm{O}_{1 \mathrm{w}}-\delta{ }^{13} \mathrm{C}_{\mathrm{c}}$ cross-plot showing all calcite data and linear regression with Pearson correlation $(r)$ (calcite $r_{\mathrm{c}}, p=<0.001$ ). (a) and (b) both include the Lini site Holocene Co1262 calibration data set (Lacey et al., 2015).

of annual precipitation may have fallen in winter as snow. Snow is typically characterised as having much lower $\delta^{18} \mathrm{O}$ than rainfall, which reflects in-cloud equilibrium conditions and cooler condensation temperatures (Darling et al., 2006), and so would provide a further potential source for low $\delta^{18} \mathrm{O}$ (Dean et al., 2013).

Temperatures may have been sufficiently reduced during glacials to also allow (at least discontinuous) permafrost to form in the Ohrid catchment, thereby decreasing input from karst waters and perhaps restricting the inflow of water from Lake Prespa (Belmecheri et al., 2009). Lake Prespa provides a large proportion of water input to Ohrid through the underground network of karst channels, which has higher $\delta^{18} \mathrm{O}_{\mathrm{lw}}$ when compared to measured precipitation (Fig. 4; Leng et al., 2010a). This infers that during periods where glacial conditions were prevalent in the catchment, the inflow of water comprising high $\delta^{18} \mathrm{O}$ from Lake Prespa may have reduced, 


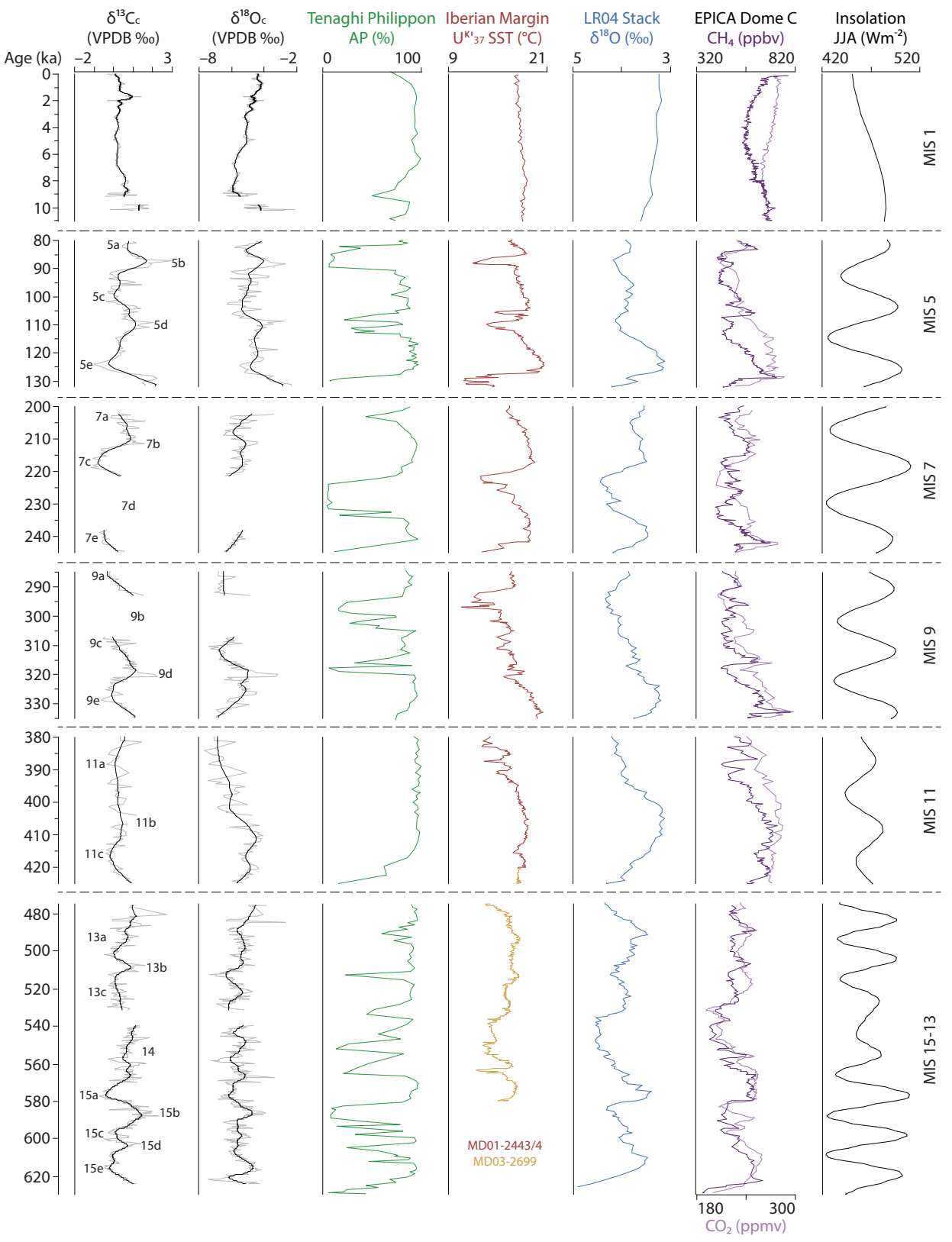

Figure 8. Comparison between Lake Ohrid $\delta^{18} \mathrm{O}_{\mathrm{c}}$ and $\delta^{13} \mathrm{C}_{\mathrm{c}}$ and other climate records, including Tenaghi Philippon arboreal pollen (AP, Tzedakis et al., 2006), Iberian Margin $U_{37}^{K^{\prime}}$ sea surface temperature composite profile (MD01-2443/4, 0-420 ka; Martrat et al., 2007; MD032699, 420-580 ka; Rodrigues et al., 2011), benthic $\delta^{18}$ O LR04 stack (inverted axis; Lisiecki and Raymo, 2005), Antarctic EPICA Dome C $\mathrm{CH}_{4}$ and $\mathrm{CO}_{2}$ (Loulergue et al., 2008; Lüthi et al., 2008), and MIS stratigraphy (Railsback et al., 2015).

and input would have instead been principally sourced from a combination of direct precipitation and surface run-off, both of which would result in lower $\delta^{18} \mathrm{O}_{\mathrm{lw}}$.

\subsubsection{Carbon isotope composition of carbonate}

When a carbonate mineral precipitates under equilibrium conditions it captures the $\delta^{13} \mathrm{C}$ of the total dissolved inorganic carbon (TDIC) of lake water. TDIC in most lakes (at neutral $\mathrm{pH}$ ) can be approximated to dissolved $\mathrm{HCO}_{3}^{-}$, which is principally derived from the dissolution of carbonate catchment rocks, soils, and atmospheric $\mathrm{CO}_{2}$ (Cohen, 2003). Consequently there are several carbon reservoirs that may influence $\delta^{13} \mathrm{C}_{\mathrm{TDIC}}$, in addition to two major fractionation effects: (1) the chemical exchange between atmospheric $\mathrm{CO}_{2}$ and dissolved $\mathrm{HCO}_{3}^{-}$and (2) kinetic processes during the formation of organic matter (Hoefs, 1980; McKenzie, 1985). In Lake Ohrid, endogenic calcite precipitated within 
the epilimnion is thought to form in equilibrium with surface waters; thus $\delta^{13} \mathrm{C}_{\mathrm{c}}$ can provide information on past variations in $\delta^{13} \mathrm{C}_{\mathrm{TDIC}}$ and associated carbon-cycle transitions (Leng and Marshall, 2004). The DEEP site record (Fig. 3) shows overall high and consistent $\delta^{13} \mathrm{C}_{\mathrm{c}}$ throughout the core $(+0.4 \pm 0.6 \%, 1 \sigma, n=924)$, which is most likely driven in part by the carbon isotope composition of inflow $\left(\delta^{13} \mathrm{C}_{\mathrm{TDIC}}\right)$. Within karst catchments the local and groundwater chemistry will be dominated by $\mathrm{Ca}^{2+}$ and $\mathrm{HCO}_{3}^{-}$ions (Cohen, 2003), and $\delta^{13} \mathrm{C}_{\mathrm{TDIC}}$ will be high as catchment limestones usually comprise ancient marine carbonates (average $\delta^{13} \mathrm{C}=0 \%$; Hudson, 1977; Jin et al., 2009) and typically range between -3 and $+3 \%$ o (Andrews et al., 1993; Hammarlund et al., 1997). Although $\delta^{13} C_{\text {TDIC }}$ has not been measured for Lake Ohrid, analysis conducted on several of the main geological units in the catchment provides average $\delta^{13} \mathrm{C}$ of $+1 \%$ (Leng et al., 2010a), which confirms that $\delta^{13} \mathrm{C}_{\text {TDIC }}$ will most probably be high as over $50 \%$ of water input to Ohrid is derived from springs fed by karst aquifers (Matzinger et al., 2006b). Over glacial-interglacial timescales, the extent to which geological sources of carbon contribute to TDIC will primarily be determined by hydrological balance and associated changes in the residence time of water passing through the karst system; lower $\delta^{13} \mathrm{C}_{\mathrm{TDIC}}$ may occur during wetter periods with a lower residence and higher $\delta^{13} \mathrm{C}_{\mathrm{TDIC}}$ in more arid periods with a higher residence time.

In opposition to geological sources of high $\delta^{13} \mathrm{C}$, a major source of carbon in ground- and river water typically derives from $\mathrm{CO}_{2}$ liberated during the decay of terrestrial organic matter (low $\delta^{13} \mathrm{C}$ ). Low $\delta^{13} \mathrm{C}_{\text {TDIC }}$ is measured for Lake Prespa water inputs (average $\delta^{13} \mathrm{C}_{\mathrm{TDIC}}=-11.5 \%$; Leng et al., 2013) and may be similar to the inflow to Lake Ohrid. Over glacial-interglacial timescales, variations in the proportion of soil-derived $\mathrm{CO}_{2}$ incorporated into catchment waters will likely influence Lake Ohrid $\delta^{13} \mathrm{C}_{\text {TDIC. }}$ In colder periods, $\delta^{13} \mathrm{C}_{\mathrm{TDIC}}$ would be higher due to poor soil development (Panagiotopoulos et al., 2014; Sadori et al., 2016); conversely, during wetter and warmer intervals the development of dense forests would promote well-developed soils (lower $\delta^{13} \mathrm{C}_{\mathrm{TDIC}}$ ) and encourage the delivery of $\mathrm{Ca}^{2+}$ and $\mathrm{HCO}_{3}^{-}$ through the dissolution of carbonate catchment rocks.

Equilibrium exchange between atmospheric $\mathrm{CO}_{2}$ and lake water will result in $\delta^{13} \mathrm{C}_{\text {TDIC }}$ of approximately $+3 \%$ (fractionation factor $+10 \%$ when in equilibrium with $\mathrm{CO}_{2}$ gas). As $\delta{ }^{13} \mathrm{C}_{\mathrm{c}}$ is thought to reflect changes in $\delta^{13} \mathrm{C}_{\mathrm{TDIC}}$, higher $\delta^{13} \mathrm{C}_{\mathrm{c}}$ in the Ohrid record may also reflect variable degrees of equilibration between atmospheric $\mathrm{CO}_{2}$ and dissolved $\mathrm{HCO}_{3}^{-}$. This process is also observed in isotope data from Lake Prespa, where low $\delta^{13} \mathrm{C}_{\mathrm{TDIC}}$ entering the lake $(-11.5 \%)$ is modified by within-lake processes to increase lake water $\delta^{13} \mathrm{C}_{\mathrm{TDIC}}$ to give the average value of $-5.2 \%$ o (Leng et al., 2013). In addition to evaporation, it is also likely that biogenic productivity drives higher $\delta^{13} \mathrm{C}_{\mathrm{TDIC}}$ in Prespa (and Ohrid) due to the preferential incorporation of ${ }^{12} \mathrm{C}$ dur- ing photosynthesis, assuming the organic carbon is exported to the lake floor and buried (Meyers and Teranes, 2001).

Evaporative drawdown will also affect $\delta^{18} \mathrm{O}$ as the preferential loss of ${ }^{16} \mathrm{O}$ during evaporation can drive higher $\delta^{18} \mathrm{O}$ resulting in covariance between $\delta^{18} \mathrm{O}$ and $\delta^{13} \mathrm{C}$. The signal of covariance will be recorded in primary lacustrine carbonates and can potentially be used to determine the degree of past hydrological closure (Talbot, 1990). The extent to which isotope measurements covary can depend on several factors, including hydrological balance, stability of the lake volume, vapour exchange, and evaporation ( $\mathrm{Li}$ and $\mathrm{Ku}, 1997)$. Covariance may therefore not simply be a function of residence time or hydrological closure (Leng et al., 2010a) and has been shown to be spatially inconsistent between Mediterranean lake sediment records (Roberts et al., 2008). Nevertheless, lake level fluctuations are thought to have occurred in Lake Ohrid, at least during MIS 6, as evidenced by the presence of subaquatic terraces on the northeast shore of the lake (Lindhorst et al., 2010). Reductions in lake level, most probably coincident with periods of regional aridity and generally lower $P / E$, may limit surface outflow, solely met at present by the river Crim Drim (66\%; Matzinger et al., 2006b), which in turn would extend lake water residence time and increase the possibility of evaporation and isotope exchange, resulting in higher $\delta^{18} \mathrm{O}$ and $\delta^{13} \mathrm{C}$. However, periods of higher covariance are generally restricted to certain intervals, for example MIS $5(r=0.53$, $p=<0.001, n=104)$, as throughout the whole core correlation between $\delta^{18} \mathrm{O}$ and $\delta^{13} \mathrm{C}$ is generally weak $(r=0.30$, $p=<0.001, n=924$; Fig. 7). In those areas where $\delta^{18} \mathrm{O}$ and $\delta^{13} \mathrm{C}$ are decoupled, local in situ process are likely to dominate the evolution of $\delta^{13} \mathrm{C}_{\mathrm{TDIC}}$ and act to buffer any climate signal (Regattieri et al., 2015).

In contrast to $\delta^{13} \mathrm{C}_{\mathrm{c}}, \delta^{13} \mathrm{C}_{\mathrm{s}}$ is higher in Lake Ohrid sediments by $>8 \%$ and has a mean value of $+12.3 \pm 0.5 \%$ o $(1 \sigma$, $n=22$ ). Higher $\delta^{13} \mathrm{C}$ is characteristic of siderite formed in non-marine sediments and is most probably associated with the incorporation of ${ }^{13} \mathrm{C}$-enriched bicarbonate derived from methanogenesis. The metabolic pathway utilised by bacteria during the reduction of organic matter strongly fractionates in favour of ${ }^{12} \mathrm{C}$, which, for isotopic mass balance, produces methane (low $\delta^{13} \mathrm{C}$ ) and proportionally enriches the bicarbonate ion in ${ }^{13} \mathrm{C}$. The methane is subsequently removed by ebullition or by emission through the stems of aquatic macrophytes, and the enriched bicarbonate is incorporated into TDIC (Curry et al., 1997).

\subsection{Climate and interglacial variability at Lake Ohrid over the past $637 \mathrm{ka}$}

The Late Quaternary is characterised by cyclic alternations between colder glacial and warmer interglacial periods, the timing and magnitude of which are principally determined by orbital-induced climate oscillations and variations in atmospheric greenhouse gas concentrations (Im- 
brie et al., 1984; Shackleton, 2000). This glacial-interglacial climate signal has been globally observed in deep marine sediments (Lisiecki and Raymo, 2005), ice cores (Jouzel et al., 2007), and continental sequences (Sun and An, 2005), which, when compared, indicate a broad correspondence over orbital timescales (Tzedakis et al., 1997; Lang and Wolff, 2011). However, comprehensive terrestrial sequences covering multiple glacial-interglacial cycles are still rare (Prokopenko et al., 2006; Tzedakis et al., 2006), especially when isotope stratigraphies are considered, and consequently the 5045-1 record can provide valuable information on climate evolution over an extended time frame. Although it is beyond the scope of this paper to look in detail at each interglacial over the last $637 \mathrm{ka}$ (MIS 15 to MIS 5), some preliminary observations can be made about their structure and consistency.

\subsubsection{MIS 16-13 (637-474 ka)}

At the transition between MIS 16 and $15, \delta^{13} \mathrm{C}_{\mathrm{c}}$ shows a prolonged trend to lower values between ca. 625 and $615 \mathrm{ka}$, whereas a $\delta^{18} \mathrm{O}_{\mathrm{c}}$ minima occurs at ca. $622 \mathrm{ka}$, following which values increase (Fig. 8) concomitant with increasing TIC and biogenic silica (BSi; Francke et al., 2016). This suggests an initial phase of higher precipitation (elevated $P / E$ ) may have been associated with a mediated catchment soil development and gradual climate warming following the MIS 16 glacial, and after ca. $622 \mathrm{ka}$ lake waters became more evaporated. Excursions to lower $\delta^{18} \mathrm{O}_{\mathrm{c}}$ and $\delta^{13} \mathrm{C}_{\mathrm{c}}$ within MIS 15, centred on ca. 615, 600, and $577 \mathrm{ka}$, are most likely related to lower $\delta^{18} \mathrm{O}$ in LR04 (Fig. 8; Lisiecki and Raymo, 2005), the Mediterranean Sea (Kroon et al., 1998), and the Ionian Sea (Rossignol-Strick and Paterne, 1999), representing an influx of glacial meltwater into the oceans and warmer conditions during MIS $15 \mathrm{e}, 15 \mathrm{c}$, and $15 \mathrm{a}$ respectively (Fig. 8). In addition, this is mirrored by high arboreal pollen (AP) at Tenaghi Philippon (Tzedakis et al., 2006) and warmer temperatures during these times also promoted vegetation growth in the catchment at Lake Ohrid (Sadori et al., 2016), leading to enhanced soil development and lower $\delta^{13} \mathrm{C}_{\mathrm{c}}$.

MIS 14 is the only glacial of the record to contain a higher proportion of TIC and TOC throughout the majority of the stage (Francke et al., 2016), indicating temperatures at Lake Ohrid did not decrease significantly to abate productivity and calcite production (therefore calcite isotope data are available for the majority of MIS 14). Hydroclimate conditions are assumed to have remained fairly similar to MIS 15 as average $\delta^{18} \mathrm{O}_{\mathrm{c}}$ remains consistent between the two stages (Fig. 8), suggesting that MIS 14 was a particularly weak glacial. Sustained warmth through MIS 14 is in agreement with a range of global records, including in sea surface temperature (SST) estimates from the Iberian margin (Fig. 8; Rodrigues et al., 2011) and South China Sea (Yu and Chen, 2011), BSi and magnetic susceptibility from Lake Baikal (Prokopenko et al.,
2002, 2006), and several proxies from Antarctic ice cores (Jouzel et al., 2007; Masson-Delmotte et al., 2010). Although overall warmer conditions may have prevailed during MIS 14 , the Ohrid record suggests that colder glacial-like conditions occurred between ca. 540 and $531 \mathrm{ka}$, which is supported by the presence of siderite (Fig. 3). $\delta^{13} \mathrm{C}_{\mathrm{c}}$ increases throughout MIS 14 imply a progressive decline in catchment soil development. A reduction in the amplitude of $\delta^{13} \mathrm{C}_{\mathrm{c}}$ oscillations, for example when compared to MIS 15, may be due to low orbital eccentricity reducing the influence of precession and insolation variability (Fig. 8).

MIS 13 in Lake Ohrid $\delta^{18} \mathrm{O}_{\mathrm{c}}$ and $\delta^{13} \mathrm{C}_{\mathrm{c}}$ represents a relatively stable period, experiencing only minor oscillations through the stage. The average isotope composition is comparable to that observed during MIS 14 and 15 (Fig. 7); however MIS 13 is generally considered to be one of the weakest interglacials of the last $800 \mathrm{ka}$ (Lang and Wolff, 2011). Similar to the onset of MIS 15, MIS $13 \mathrm{c}$ is characterised by relatively rapid transition to lower $\delta^{18} \mathrm{O}_{\mathrm{c}}$ at ca. $529 \mathrm{ka}$ followed by increasing values through to ca. $521 \mathrm{ka}$, associated with a gradual concomitant trend to lower $\delta^{13} \mathrm{C}_{\mathrm{c}}$ (Fig. 8). An excursion to higher $\delta^{13} \mathrm{C}_{\mathrm{c}}$ centred around ca. $510 \mathrm{ka}$ is probably linked to cooler conditions and the onset of MIS $13 \mathrm{~b}$, and a transition to higher $\delta^{18} \mathrm{O}_{\mathrm{c}}$ suggests lower $P / E$, which is similar to observations from Tenaghi Philippon and Antarctic ice cores that indicate reduced AP and lower reconstructed temperatures (Tzedakis et al., 2006; Jouzel et al., 2007). The LR04 record also exhibits higher $\delta^{18} \mathrm{O}$ at this time, signifying an expansion of global ice volume (Fig. 8; Lisiecki and Raymo, 2005). A shift to lower $\delta^{18} \mathrm{O}_{\mathrm{c}}$ and $\delta^{13} \mathrm{C}_{\mathrm{c}}$ at ca. $502 \mathrm{ka}$ most likely represents the onset of MIS 13a, where $\delta^{13} \mathrm{C}_{\mathrm{c}}$ is the lowest of the stage (ca. 530 to $474 \mathrm{ka}$ ), suggesting MIS 13a most probably experienced warmer conditions than MIS 13c. The timing of interglacial conditions is unique within the Lake Ohrid record, and correspondingly in global sequences, as minimum ice volume (Lisiecki and Raymo, 2005) and maximum warmth (Jouzel et al., 2007; Loulergue et al., 2008) occurred in the final substage of the MIS rather than directly following the glacial termination (Fig. 8). This was most probably due to MIS 14 experiencing only weak glacial conditions resulting in a low-amplitude glacial termination (Voelker et al., 2010). Peaks to higher $\delta^{18} \mathrm{O}_{\mathrm{c}}$ and $\delta^{13} \mathrm{C}_{\mathrm{c}}$ toward the end of MIS 13a are coincident with an increased proportion of siderite in sediments (Fig. 3), and so fluctuations may be the result of a mixed carbonate composition rather than due to environmental change.

\subsubsection{MIS $11(425-380 \mathrm{ka})$}

MIS 11 is thought to have a characteristic orbital and climate configuration potentially analogous to that of the Holocene (Loutre and Berger, 2003) and follows a strong and relatively wet glacial MIS 12 at Lake Ohrid (Sadori et al., 2016). Following the glacial termination $\delta^{18} \mathrm{O}_{\mathrm{c}}$ is low (around $-6 \%$ ) and increases over the next $15 \mathrm{ka}$ to a maximum $(-4 \%$ ) at 
ca. $410 \mathrm{ka}$, whereas $\delta^{13} \mathrm{C}_{\mathrm{c}}$ transitions to lower values between ca. 425 and $410 \mathrm{ka}$, suggesting a prolonged period of warm and relatively stable conditions. This period most likely corresponds to MIS $11 \mathrm{c}$, where warmer, wetter conditions are supported by high TIC and AP at Lake Ohrid (Francke et al., 2016; Sadori et al., 2016). The overall progression of $\delta^{18} \mathrm{O}_{\mathrm{c}}$ and $\delta^{13} \mathrm{C}_{\mathrm{c}}$ through MIS 11c corresponds to high SST at the Iberian Margin (Fig. 8; Rodrigues et al., 2011) and compares well with the development of $\mathrm{CO}_{2}$ and $\mathrm{CH}_{4}$ measured from the EDC Antarctic ice core record (Loulergue et al., 2008; Lüthi et al., 2008). A distinct $\delta^{18} \mathrm{O}_{\mathrm{c}}$ and $\delta^{13} \mathrm{C}_{\mathrm{c}}$ maxima centred around ca. $405 \mathrm{ka}$ is likely associated with colder conditions and a drier environment (lower $P / E$ ) through stadial phase MIS $11 \mathrm{~b}$, which is supported by higher K intensity, lower TIC, and a substantial decrease in AP (Francke et al., 2016; Sadori et al., 2016). An overall trend to lower $\delta^{18} \mathrm{O}_{\mathrm{c}}$ and $\delta^{13} \mathrm{C}_{\mathrm{c}}$ through MIS 11a (ca. 402 to $385 \mathrm{ka}$ ) shows greater variability in comparison to MIS $11 \mathrm{c}$, suggesting that the stability of hydroclimate conditions changed after peak interglacial conditions. Greater variability after ca. $400 \mathrm{ka}$ is also seen in other proxies from Lake Ohrid (TIC, BSi; Francke et al., 2016), as well as in reconstructed SST at the Iberian Margin (Rodrigues et al., 2011) and atmospheric $\mathrm{CH}_{4}$ and temperature profiles from Antarctic ice cores (Fig. 8; Petit et al., 1999; Jouzel et al., 2007). Following the climatic optimum of MIS $11 \mathrm{c}, \delta^{18} \mathrm{O}_{\mathrm{c}}$ transitions to the lowest value of the record at ca. $384 \mathrm{ka}(-7.6 \%)$, over which time there is an increase in global ice volume and decrease in atmospheric greenhouse gas concentrations observed through MIS 11b and 11a (Lisiecki and Raymo, 2005; Loulergue et al., 2008). A trend to lower $\delta^{18} \mathrm{O}_{\mathrm{c}}$ at Ohrid also traces reducing SST in the North Atlantic and on the Iberian Margin (Stein et al., 2009; Rodrigues et al., 2011). The progression to lower $\delta^{18} \mathrm{O}_{c}$ during a period of overall cooling is expected, given that the reconstructed $\delta^{18} \mathrm{O}_{1 \mathrm{w}}$ from glacial siderite is typically lower than interglacial $\delta^{18} \mathrm{O}_{\mathrm{lw}}$, as calculated from calcite (Fig. 3).

\subsubsection{MIS 9 (335-285 ka)}

The initial ca. $4 \mathrm{ka}$ of MIS 9 is marked by a transition to higher $\delta^{18} \mathrm{O}_{\mathrm{c}}$ and lower $\delta^{13} \mathrm{C}_{\mathrm{c}}$, similar to previous interglacial stages. After ca. $330 \mathrm{ka}$ variations in $\delta^{18} \mathrm{O}_{\mathrm{c}}$ and $\delta^{13} \mathrm{C}_{\mathrm{c}}$ are coupled and a minimum in both values is observed around ca. $329 \mathrm{ka}$ (Fig. 8), which is assumed to correspond to peak interglacial conditions during MIS 9e. The onset of full interglacial conditions during MIS 9e is indicated to be relatively rapid, given that a maximum of ca. 6 ka elapses between the onset of calcite precipitation and peak interglacial conditions, which is consistent with warming at the start of MIS 9 observed in AP from Tenaghi Philippon (Tzedakis et al., 2006) and SST from the Iberian Margin (Fig. 8; Martrat et al., 2007). An abrupt transition to the highest $\delta^{18} \mathrm{O}_{\mathrm{c}}$ and $\delta^{13} \mathrm{C}_{\mathrm{c}}$ of MIS 9 between ca. 321 and $318 \mathrm{ka}$ is coincident with lower TIC, BSi, and AP at Lake Ohrid (Francke et al., 2016;
Sadori et al., 2016). A reduction in Pinus populations in the Ohrid catchment alongside lower $P / E$ indicates an overall drier climate, which is also documented at Tenaghi Philippon (Tzedakis et al., 2006) and most likely associated with stadial conditions during MIS 9d. The subsequent transition to lower $\delta^{18} \mathrm{O}_{\mathrm{c}}$ and $\delta^{13} \mathrm{C}_{\mathrm{c}}$ towards ca. $310 \mathrm{ka}$ is probably associated with a warmer climate, higher precipitation and $P / E$ during interstadial MIS 9c, reflected at Tenaghi Philippon by higher AP (Tzedakis et al., 2006) and moderately lower $\delta^{18} \mathrm{O}$ in the LR04 stack (Fig. 8; Lisiecki and Raymo, 2005). A subsequent break in TIC preservation occurs between ca. 308 and $293 \mathrm{ka}$, which is preceded by a transition to higher $\delta^{18} \mathrm{O}_{\mathrm{c}}$ and $\delta^{13} \mathrm{C}_{\mathrm{c}}$, suggesting a drier climate prevailed, and is most likely associated with stadial MIS 9b. This interval is also indicated to be an extended period of cold and dry conditions at Lake Ohrid by low TIC and BSi (Francke et al., 2016) and low AP (Sadori et al. 2016), where the presence of siderite advocates that a glacial-like climate state persisted throughout much of the stadial phase (Fig. 3). A trend to lower $\delta^{13} \mathrm{C}_{\mathrm{c}}$ between ca. 293 and 286 ka closely corresponds to an increase in TIC, BSi, and AP, and a rapid shift to lower $\delta^{18} \mathrm{O}_{\mathrm{c}}$ after ca. $293 \mathrm{ka}$ indicates the onset of warmer and wetter conditions during interstadial MIS 9a. Low and relatively stable $\delta^{18} \mathrm{O}_{\mathrm{c}}$ values between ca. 292 and $288 \mathrm{ka}$ imply a fresh lake system and higher $P / E$, which may be driven by increased precipitation in association with the deposition of sapropel $S^{\prime}$ in the Mediterranean Sea (Ziegler et al., 2010) and summer insolation maxima (Fig. 8; Laskar et al., 2004). Overall, low $\delta^{18} \mathrm{O}_{\mathrm{c}}$ through MIS 9 and its calculated $\delta^{18} \mathrm{O}_{\mathrm{lw}}$ are coincident with similar $\delta^{18} \mathrm{O}_{\mathrm{lw}}$ values from siderite during MIS 10 and MIS 8 (Fig. 3), indicating glacial and interglacial lake water broadly converge through this interval.

\subsubsection{MIS 7 (243-191 ka)}

MIS 7 at Lake Ohrid is characterised by three distinct phases of calcite preservation (Fig. 3; Francke et al., 2016), which most likely correspond to MIS sub-stages $7 \mathrm{e}, 7 \mathrm{c}$, and $7 \mathrm{a}$ (Railsback et al., 2015). The first peak in TIC between ca. 245 and $238 \mathrm{ka}$ is associated with initially low and increasing $\delta^{18} \mathrm{O}_{\mathrm{c}}$ and high but decreasing $\delta^{13} \mathrm{C}_{\mathrm{c}}$, which both show a higher amplitude of variability after ca. $242 \mathrm{ka}$. Increasing $\delta^{18} \mathrm{O}_{\mathrm{c}}$ suggests a transition from wetter to drier climate through to ca. $238 \mathrm{ka}$; however, warm and wet conditions are indicated by overall low $\delta^{18} \mathrm{O}_{\mathrm{c}}$ coincident with high TIC, BSi, and AP (Francke et al., 2016; Sadori et al., 2016). This period most probably corresponds to interglacial MIS $7 \mathrm{e}$ and is coincident with warming indicated by arboreal expansion at the Ioannina (Roucoux et al., 2008) and Tenaghi Philippon (Fig. 8; Tzedakis et al., 2006) basins in Greece and at Lake Van in Turkey (Litt et al., 2014). Overall warming is supported by higher reconstructed SST for the Adriatic Sea (Piva et al., 2008) and on the Iberian Margin (Fig. 8; Martrat et al., 2007). A cessation of TIC production between ca. 238 and $221 \mathrm{ka}$ indicates a colder, extended glacial-like climate 
state during stadial MIS 7d, which is also suggested by the presence of siderite (Fig. 3). A relatively abrupt decrease in $\delta^{13} \mathrm{C}_{\mathrm{c}}$ after ca. $221 \mathrm{ka}$ marks the onset of warmer conditions at Lake Ohrid and the transition to interstadial MIS 7c. An interval of low $\delta^{13} \mathrm{C}_{\mathrm{c}}$ between ca. 221 and 212 ka represents the lowermost values of the core, which suggests MIS 7c may have experienced warmer conditions than during the full interglacial (MIS 7e) and is supported by a higher TIC plateau (Francke et al., 2016). In addition, a greater diversity of AP is observed at Tenaghi Philippon alongside a greater abundance of thermophilous taxa (Tzedakis et al., 2003b) and higher BSi at Lake Baikal (Prokopenko et al., 2006). Although $\mathrm{CO}_{2}$ and $\mathrm{CH}_{4}$ concentrations were lower in MIS 7c (Loulergue et al., 2008; Lüthi et al., 2008), higher summer insolation during MIS 7c most likely promoted warmer climate conditions (Fig. 8). A change to stadial conditions is suggested around ca. $211 \mathrm{ka}$ by a shift to higher $\delta^{18} \mathrm{O}_{\mathrm{c}}$ and $\delta^{13} \mathrm{C}_{\mathrm{c}}$, as well as the presence of siderite (Fig. 3), which likely corresponds to MIS 7b. Decreasing $\delta^{13} \mathrm{C}_{\mathrm{c}}$ and an increasing $\delta^{18} \mathrm{O}_{\mathrm{c}}$ trend between ca. 210 and $202 \mathrm{ka}$ most probably correspond to interstadial MIS 7a; however, unlike substages $7 \mathrm{e}$ and $7 \mathrm{c}$, the interval is characterised by large amplitude coupled oscillations in both $\delta^{18} \mathrm{O}_{\mathrm{c}}$ and $\delta^{13} \mathrm{C}_{\mathrm{c}}$. A change in climate stability is also reflected in AP at Tenaghi Philippon (Tzedakis et al., 2003b) and in speleothem $\delta^{18} \mathrm{O}$ from northern Israel (BarMatthews et al., 2003). After ca. 202 ka siderite is observed to be abundant through MIS 6 .

\subsubsection{MIS 5 (130-80 ka)}

MIS 5 has been characterised as one of the strongest warm periods of the last $800 \mathrm{ka}$ (Lisiecki and Raymo, 2005; Jouzel et al., 2007; Lang and Wolff, 2011). At Lake Ohrid, the highest $\delta^{18} \mathrm{O}_{\mathrm{c}}$ and $\delta^{13} \mathrm{C}_{\mathrm{c}}$ of the record are observed during MIS 5 (Fig. 8), suggesting low $P / E$ and high rates of evaporation, which may be related to severe lake level changes inferred during MIS 5 (Lindhorst et al., 2010). A rapid transition to lower $\delta^{18} \mathrm{O}_{\mathrm{c}}$ and $\delta^{13} \mathrm{C}_{\mathrm{c}}$ after ca. $129 \mathrm{ka}$ is most likely associated with the onset of full interglacial conditions during MIS 5e. A climatic optimum is probably associated with the point of lowest isotope values at ca. $124 \mathrm{ka}$; however, $\delta^{18} \mathrm{O}_{\mathrm{c}}$ decreases at a faster rate in comparison to $\delta^{13} \mathrm{C}_{\mathrm{c}}$ (Fig. 8). This may be due to terrestrial and lacustrine proxies decoupling due to local effects of ice cap and snowfield meltwater entering the lake, as is observed at Lake Ioannina (Wilson et al., 2015). Local ice caps on the mountains surrounding Lake Ohrid are indicated for the Last Glacial by catchment moraine deposits (Ribolini et al., 2011) and are likely to have been present during early glacials, such as MIS 6 (Francke et al., 2016). Overall, the interval of lower $\delta^{18} \mathrm{O}_{\mathrm{c}}$ and $\delta^{13} \mathrm{C}_{\mathrm{c}}$ is coincident with higher Mediterranean SST (Piva et al., 2008; Martrat et al., 2014), the deposition of sapropel S5 (Ziegler et al., 2010), and greater regional precipitation (Bar-Matthews et al., 2003; Drysdale et al., 2005). An increase in $\delta^{18} \mathrm{O}_{c}$ and $\delta^{13} \mathrm{C}_{\mathrm{c}}$ values after ca. $114 \mathrm{ka}$ signals the onset of stadial conditions (MIS 5d) and infers that interglacial conditions persisted for approximately $15 \mathrm{ka}$, which is in broad agreement with reported durations from other regional sequences (Tzedakis et al., 2003a; Brauer et al., 2007; Pickarski et al., 2015). High $\delta^{18} \mathrm{O}_{\mathrm{c}}$ and $\delta^{13} \mathrm{C}_{\mathrm{c}}$ between ca. 114 and $108 \mathrm{ka}$ suggest drier conditions during MIS $5 \mathrm{~d}$, which is supported by the presence of siderite and a reduction in AP (Sadori et al., 2016). An excursion to lower $\delta^{13} C_{c}$ between ca. 108 and $91 \mathrm{ka}$ is coincident with higher AP at both Lake Ohrid and Tenaghi Philippon (Tzedakis et al., 2003b; Sadori et al., 2016) and higher SST at the Iberian Margin (Fig. 8; Martrat et al., 2007), which suggests warmer temperatures during MIS $5 \mathrm{c} . \delta^{18} \mathrm{O}_{\mathrm{c}}$ is observed to be lower in MIS $5 \mathrm{c}$ than during full interglacial conditions through MIS 5e (Fig. 8), which could be due to refilling after a lake water lowstand (Lindhorst et al., 2010). Alternatively, given higher insolation and atmospheric $\mathrm{CO}_{2}$ and $\mathrm{CH}_{4}$ concentrations during MIS $5 \mathrm{e}$ (Petit et al., 1999; Laskar et al., 2004; Loulergue et al., 2008), evaporation may have been stronger and driven higher $\delta^{18} \mathrm{O}_{\mathrm{c}}$, even under a regime of elevated regional precipitation (BarMatthews et al., 2003; Drysdale et al., 2005). A transition to higher $\delta^{18} \mathrm{O}_{\mathrm{c}}$ and $\delta^{13} \mathrm{C}_{\mathrm{c}}$ after ca. $91 \mathrm{ka}$ corresponds to reduced TIC, BSi, and AP (Francke et al., 2016; Sadori et al., 2016) and high siderite abundance, which are assumed to be associated with stadial conditions during MIS 5b. The transition to higher isotope values occurs over a shorter time interval in comparison to MIS 5d, suggesting MIS 5b probably experienced a more produced change to cold and dry climate conditions. This is supported by higher speleothem $\delta^{18} \mathrm{O}$ at Soreq Cave (Bar-Matthews et al., 2003), lower reconstructed SST from the Adriatic and Alboran seas (Martrat et al. 2004; Piva et al., 2008), and lower atmospheric $\mathrm{CO}_{2}$ (Fig. 8; Petit et al., 1999). A decrease in $\delta^{18} \mathrm{O}_{\mathrm{c}}$ and $\delta^{13} \mathrm{C}_{\mathrm{c}}$ after ca. $86 \mathrm{ka}$ is thought to be related to the onset of interstadial conditions during MIS 5a. A minimum in both isotope values centred around ca. $82 \mathrm{ka}$ infers climate conditions may have been wetter and warmer toward the end of the stage. A transition to lower $\delta^{18} \mathrm{O}$ is also observed at Soreq Cave (Bar-Matthews et al., 2003), suggesting regional rainfall may have been enhanced toward the end of MIS 5a, which may be related to a coincident peal in summer insolation (Fig. 8; Laskar et al., 2004).

\section{Conclusions}

Here, new stable isotope data from the ICDP SCOPSCO 5045-1 composite core provide information on hydroclimate variability in the northern Mediterranean over the last $637 \mathrm{ka}$ and represent one of the most extensive terrestrial isotope records available for the region. Modern lake water data (Leng et al., 2010a) and a high-resolution Holocene calibration data set (Lacey et al., 2015) show that contemporary lake water is evaporated and that variations in $\delta^{18} \mathrm{O}$ principally reflect changes in $P / E$ driven by regional water balance. Iso- 
tope data from calcite are continuous through intervals associated with high TIC (interglacials and interstadials), and discrete bands of siderite are present during periods characterised by low TIC (glacials and stadial). The siderite is considered to be early diagenetic and therefore, like calcite, can be used as a proxy for past lake water conditions, assuming at shallow depths $\delta^{18} \mathrm{O}$ of the lake water and pore water at the same. Overall, calculated $\delta^{18} \mathrm{O}_{\mathrm{lw}}$ is lower during glacial periods indicating lake water was fresher in comparison to interglacials most probably due to a change in summer temperature, evaporation rates, and the proportion of winter precipitation falling as snow. The isotope data suggest largely stable conditions persisted through MIS 15-13, inferring MIS 14 to be a particular weak glacial. A transition to lower $\delta^{18} \mathrm{O}_{\mathrm{c}}$ is observed in the later stages of MIS 11 through to MIS 9, followed by a change to higher values through MIS 7 and evaporated conditions during MIS 5. The pattern of variability observed in the Lake Ohrid sequence reflects comparable changes in both regional and global palaeoclimate records, and our data highlight the potential for future work on the 5045-1 composite profile to provide evidence for long-term climate change in the Mediterranean, as a prerequisite for better understanding the influence of major environmental events on biological evolution within the lake.

Acknowledgements. Isotope analysis was conducted at the Stable Isotope Facility (part of the NERC Isotope Geosciences Facility at the British Geological Survey) and forms part of the $\mathrm{PhD}$ research of JHL funded by the British Geological Survey University Funding Initiative (BUFI). Thanks go to the staff at BGS who assisted with preparation and analysis of isotope samples, in particular Jonathan Dean and Christopher Kendrick, and to John Fletcher who prepared the thin sections. The SCOPSCO Lake Ohrid drilling campaign was funded by ICDP, the German Ministry of Higher Education and Research, the German Research Foundation, the University of Cologne, the British Geological Survey, the INGV and CNR (both Italy), and the governments of the republics of Macedonia (FYROM) and Albania. Logistic support was provided by the Hydrobiological Institute in Ohrid. Drilling was carried out by Drilling, Observation and Sampling of the Earth's Continental Crust's (DOSECC) and using the Deep Lake Drilling System (DLDS). Special thanks are due to Beau Marshall and the drilling team. Ali Skinner and Martin Melles provided immense help and advice during logistic preparation and the drilling operation. The authors thank Graham Wilson and an anonymous reviewer for their constructive comments and positive suggestions on this manuscript.

Edited by: F. Wagner-Cremer

\section{References}

Albrecht, C. and Wilke, T.: Ancient Lake Ohrid: biodiversity and evolution, Hydrobiologia, 615, 103-140, 2008.

Amataj, S., Anovski, T., Benischke, R., Eftimi, R., Gourcy, L. L., Kola, L., Leontiadis, I., Micevski, E., Stamos, A., and Zoto, J.:
Tracer methods used to verify the hypothesis of Cvijić about the underground connection between Prespa and Ohrid Lake, Environ. Geol., 51, 749-753, 2007.

Anovski, T.: Progress in the Study of Prespa Lake Using Nuclear and Related Techniques, IAEA Regional Project RER/8/008, Skopje, Macedonia, 2001.

Anovski, T., Andonovski, B., and Mineva, B.: Study of the hydrological relationship between lakes Ohrid and Prespa, IAEA-SMVienna, 11-15 March 1991.

Anovski, T., Naumovski, J., Kacurkov, D., and Kirkov, P.: A study of the origin of waters of St. Naum Springs, Lake Ohrid, Fisika, $12,1980$.

Anovski, T., Leontiadis, I., and Zoto, J.: Isotope Data, in: Progress in the Study of Prespa Lake Using Nuclear and Related Techniques, IAEA Regional Project RER/8/008, edited by: Anovski, T., Skopje, Macedonia, 2001.

Andrews, J. E., Riding, R., and Dennis, P. F.: Stable isotopic compositions of Recent freshwater cyanobacterial carbonates from the British Isles: local and regional environmental controls, Sedimentology, 40, 303-314, 1993.

Antonioli, F., Bard, E., Potter, E.-K., Silenzi, S., and Improta, S.: 215-ka History of sea-level oscillations from marine and continental layers in Argentarola Cave speleothems (Italy), Global Planet. Change, 43, 57-78, 2004.

Bard, E., Delaygue, G., Rostek, F., Antonioli, F., Silenzi, S., and Schrag, D. P.: Hydrological conditions over the western Mediterranean basin during the deposition of the cold Sapropel 6 (ca. 175 kyr BP), Earth Planet. Sc. Lett., 202, 481-494, 2002.

Bar-Matthews, M., Ayalon, A., and Kaufman, A.: Late Quaternary Paleoclimate in the Eastern Mediterranean Region from Stable Isotope Analysis of Speleothems at Soreq Cave, Israel, Quaternary Res., 47, 155-168, 1997.

Bar-Matthews, M., Ayalon, A., Kaufman, A., and Wasserburg, G. J.: The Eastern Mediterranean paleoclimate as a reflection of regional events: Soreq cave, Israel, Earth Planet. Sc. Lett., 166, 85-95, 1999.

Bar-Matthews, M., Ayalon, A., Gilmour, M., Matthews, A., and Hawkesworth, C. J.: Sea-land oxygen isotopic relationships from planktonic foraminifera and speleothems in the Eastern Mediterranean region and their implication for paleorainfall during interglacial intervals, Geochim. Cosmochim. Ac., 67, 31813199, 2003.

Baumgarten, H., Wonik, T., Tanner, D. C., Francke, A., Wagner, B., Zanchetta, G., Sulpizio, R., Giaccio, B., and Nomade, S.: Age-depth model of the past $630 \mathrm{kyr}$ for Lake Ohrid (FYROM/Albania) based on cyclostratigraphic analysis of downhole gamma ray data, Biogeosciences, 12, 7453-7465, doi:10.5194/bg-12-7453-2015, 2015.

Belmecheri, S., Namiotko, T., Robert, C., von Grafenstein, U., and Danielopol, D. L.: Climate controlled ostracod preservation in Lake Ohrid (Albania, Macedonia), Palaeogeogr. Palaeocl., 277, 236-245, 2009.

Belmecheri, S., von Grafenstein, U., Andersen, N., EymardBordon, A., Régnier, D., Grenier, C., and Lézine, A.-M.: Ostracod-based isotope record from Lake Ohrid (Balkan Peninsula) over the last $140 \mathrm{ka}$, Quaternary Sci. Rev., 29, 3894-3904, 2010 . 
Bordon, A., Peyron, O., Lézine, A.-M., Brewer, S., and Fouache, E.: Pollen-inferred Late-Glacial and Holocene climate in southern Balkans (Lake Maliq), Quatern. Int., 200, 19-30, 2009.

Bowen, G. J.: The Online Isotopes in Precipitation Calculator, http: //www.waterisotopes.org, last access: 27 July 2015.

Bowen, G. J., Wassenaar, L. I., and Hobson, K. A.: Global application of stable hydrogen and oxygen isotopes to wildlife forensics, Oecologia, 143, 337-348, 2005.

Brauer, A., Allen, J. R., Mingram, J., Dulski, P., Wulf, S., and Huntley, B.: Evidence for last interglacial chronology and environmental change from Southern Europe, P. Natl. Acad. Sci. USA, 104, 450-455, 2007.

Chukanov, N. V.: Infrared spectra of mineral species, Springer, Dordrecht, Heidelberg, New York, London, 2014.

Cohen, A. S.: Paleolimnology: The History and Evolution of Lake Systems, Oxford University Press, Oxford, 2003.

Craig, H.: Isotopic Variations in Meteoric Waters, Science, 133, 1702-1703, 1961.

Curry, B. B., Anderson, T. F., and Lohmann, K. C.: Unusual carbon and oxygen isotopic ratios of ostracodal calcite from last interglacial (Sangamon episode) lacustrine sediment in Raymond Basin, Illinois, USA, J. Paleolimnol., 17, 421-435, 1997.

Dansgaard, W.: Stable isotopes in precipitation, Tellus, 16, 436468,1964

Darling, W. G., Bath, A. H., Gibson, J. J., and Rozanski, K.: Isotopes in Palaeoenvironmental Research: 1. Isotopes in Water, Springer, the Netherlands, 2006.

Dean, J. R., Jones, M. D., Leng, M. J., Sloane, H. J., Roberts, C. N., Woodbridge, J., Swann, G. E. A., Metcalfe, S. E., Eastwood, W. J., and Yiğitbaşığlu, H.: Palaeo-seasonality of the last two millennia reconstructed from the oxygen isotope composition of carbonates and diatom silica from Nar Gölü, central Turkey, Quaternary Sci. Rev., 66, 35-44, 2013.

Drysdale, R. N., Zanchetta, G., Hellstrom, J. C., Fallick, A. E., and Zhao, J.-x.: Stalagmite evidence for the onset of the Last Interglacial in southern Europe at $129 \pm 1 \mathrm{ka}$, Geophys. Res. Lett., 32, L24708, doi:10.1029/2005GL024658, 2005.

Eastwood, W. J., Leng, M. J., Roberts, N., and Davis, B.: Holocene climate change in the eastern Mediterranean region: a comparison of stable isotope and pollen data from Lake Gölhisar, southwest Turkey, J. Quaternary Sci., 22, 327-341, 2007.

Eftimi, R. and Zoto, J.: Isotope study of the connection of Ohrid and Prespa lakes, International Symposium "Towards Integrated Conservation and Sustainable Development of Transboundary Macro and Micro Prespa Lakes", 24-26 October 1997, Korcha, Albania, 1997.

Eftimi, R., Micevski, E., and Stamos, A.: Geological and hydrogeological conditions of the Prespa Region, in: Progress in the Study of Prespa Lake Using Nuclear and Related Techniques, IAEA Regional Project RER/8/008, edited by: Anovski, T., Skopje, Macedonia, 2001.

Föller, K., Stelbrink, B., Hauffe, T., Albrecht, C., and Wilke, T.: Constant diversification rates of endemic gastropods in ancient Lake Ohrid: ecosystem resilience likely buffers environmental fluctuations, Biogeosciences, 12, 7209-7222, doi:10.5194/bg12-7209-2015, 2015.

Francke, A., Wagner, B., Leng, M. J., and Rethemeyer, J.: A Late Glacial to Holocene record of environmental change from
Lake Dojran (Macedonia, Greece), Clim. Past, 9, 481-498, doi:10.5194/cp-9-481-2013, 2013.

Francke, A., Wagner, B., Just, J., Leicher, N., Gromig, R., Baumgarten, H., Vogel, H., Lacey, J. H., Sadori, L., Wonik, T., Leng, M. J., Zanchetta, G., Sulpizio, R., and Giaccio, B.: Sedimentological processes and environmental variability at Lake Ohrid (Macedonia, Albania) between $637 \mathrm{ka}$ and the present, Biogeosciences, 13, 1179-1196, doi:10.5194/bg-13-1179-2016, 2016.

Frogley, M. R., Tzedakis, P. C., and Heaton, T. H. E.: Climate Variability in Northwest Greece During the Last Interglacial, Science, 285, 1886-1889, 1999.

Frogley, M. R., Griffiths, H. I., and Heaton, T. H. E.: Historical biogeography and Late Quaternary environmental change of Lake Pamvotis, Ioannina (north-western Greece): evidence from ostracods, J. Biogeogr., 28, 745-756, 2001.

García-Ruiz, J. M., López-Moreno, J. I., Vicente-Serrano, S. M., Lasanta-Martínez, T., and Beguería, S.: Mediterranean water resources in a global change scenario, Earth-Sci. Rev., 105, 121139, 2011.

Giaccio, B., Regattieri, E., Zanchetta, G., Nomade, S., Renne, P. R., Sprain, C. J., Drysdale, R. N., Tzedakis, P. C., Messina, P., Scardia, G., Sposato, A., and Bassinot, F.: Duration and dynamics of the best orbital analogue to the present interglacial, Geology, 43, 603-606, 2015.

Giannakopoulos, C., Le Sager, P., Bindi, M., Moriondo, M., Kostopoulou, E., and Goodess, C. M.: Climatic changes and associated impacts in the Mediterranean resulting from a $2{ }^{\circ} \mathrm{C}$ global warming, Global Planet. Change, 68, 209-224, 2009.

Giorgi, F.: Climate change hot-spots, Geophys. Res. Lett., 33, L08707, doi:10.1029/2006GL025734, 2006.

Granina, L., Müller, B., and Wehrli, B.: Origin and dynamics of Fe and $\mathrm{Mn}$ sedimentary layers in Lake Baikal, Chem. Geol., 205, 55-72, 2004.

Hadzisce, S.: Das Mixophänomen im Ohridsee im Laufe der Jahre 1941/42-1964/65, Verhandlungen des Internationalen Verein Limnologie, 16, 134-138, 1966.

Hammarlund, D., Aravena, R., Barnekow, L., Buchardt, B., and Possnert, G.: Multi-component carbon isotope evidence of early Holocene environmental change and carbon-flow pathways from a hard-water lake in northern Sweden, J. Paleolimnol., 18, 219233, 1997.

Harding, A., Palutikof, J., and Holt, T.: The climate system, in: The Physical Geography of the Mediterranean, edited by: Woodward, J., Oxford University Press, Oxford, 69-88, 2009.

Hoefs, J.: Stable Isotope Geochemistry, Springer-Verlag, Berlin, 1980.

Hollis, G. E. and Stevenson, A. C.: The physical basis of the Lake Mikri Prespa systems: geology, climate, hydrology and water quality, Hydrobiologia, 351, 1-19, 1997.

Hudson, J. D.: Stable isotopes and limestone lithification, J. Geol. Soc., 133, 637-660, 1977.

Imbrie, J., Hays, J. D., Martinson, D. G., McIntyre, A., Mix, A. C., Morley, J. J., Pisias, N. G., Prell, W. L., and Shackleton, N.: The orbital theory of Pleistocene climate : support from a revised chronology of the marine $\delta^{18} \mathrm{O}$ record, in: Milankovitch and Climate (Part 1), edited by: Berger, A., Imbrie, J., Hays, H., Kukla, G., and Saltzman, B., Reidel, Hingham, Mass., 1984.

Jin, L., Ogrinc, N., Hamilton, S. K., Szramek, K., Kanduc, T., and Walter, L. M.: Inorganic carbon isotope systematics in soil 
profiles undergoing silicate and carbonate weathering (Southern Michigan, USA), Chem. Geol., 264, 139-153, 2009.

Jones, M. D., Roberts, C. N., and Leng, M. J.: Quantifying climatic change through the last glacial-interglacial transition based on lake isotope palaeohydrology from central Turkey, Quaternary Res., 67, 463-473, 2007.

Jordanoska, B., Kunz, M. J., Stafilov, T., and Wuest, A.: Temporal variability in physico-chemical properties of St. Naum karst springs feeding Lake Ohrid, Ecology and Protection of the Environment, 13, 3-11, 2010.

Jouzel, J., Masson-Delmotte, V., Cattani, O., Dreyfus, G., Falourd, S., Hoffmann, G., Minster, B., Nouet, J., Barnola, J. M., Chappellaz, J., Fischer, H., Gallet, J. C., Johnsen, S., Leuenberger, M., Loulergue, L., Luethi, D., Oerter, H., Parrenin, F., Raisbeck, G., Raynaud, D., Schilt, A., Schwander, J., Selmo, E., Souchez, R., Spahni, R., Stauffer, B., Steffensen, J. P., Stenni, B., Stocker, T. F., Tison, J. L., Werner, M., and Wolff, E. W.: Orbital and Millennial Antarctic Climate Variability over the Past 800,000 Years, Science, 317, 793-796, 2007

Kim, S. T. and O'Neil, J. R.: Equilibrium and nonequilibrium oxygen isotope effects in synthetic carbonates, Geochim. Cosmochim. Ac., 61, 3461-3475, 1997.

Kroon, D., Alexander, I., Little, M., Lourens, L. J., Mattewson, A., Robertson, A. H. F., and Sakamoto, T.: Oxygen isotope and sapropel stratigraphy in the eastern Mediterranean during the last 3.2 million years, Proceedings of the Ocean Drilling Program, Scientific Results, 160, 181-189, 1998.

Kwiecien, O., Stockhecke, M., Pickarski, N., Heumann, G., Litt, T., Sturm, M., Anselmetti, F., Kipfer, R., and Haug, G. H.: Dynamics of the last four glacial terminations recorded in Lake Van, Turkey, Quaternary Sci. Rev., 104, 42-52, 2014.

Lacey, J. H., Francke, A., Leng, M. J., Vane, C. H., and Wagner, B.: A high-resolution Late Glacial to Holocene record of environmental change in the Mediterranean from Lake Ohrid (Macedonia/Albania), Int. J. Earth Sci., 104, 1623-1638, 2015.

Lang, N. and Wolff, E. W.: Interglacial and glacial variability from the last $800 \mathrm{ka}$ in marine, ice and terrestrial archives, Clim. Past, 7, 361-380, doi:10.5194/cp-7-361-2011, 2011.

Laskar, J., Robutel, P., Joutel, F., Gastineau, M., Correia, A. C. M., and Levrard, B.: A long-term numerical solution for the insolation quantities of the Earth, Astron. Astrophys., 428, 261-285, 2004

Leicher, N., Zanchetta, G., Sulpizio, R., Giaccio, B., Wagner, B., Nomade, S., Francke, A., and Del Carlo, P.: First tephrostratigraphic results of the DEEP site record from Lake Ohrid, Macedonia, Biogeosciences Discuss., 12, 15411-15460, doi:10.5194/bgd-12-15411-2015, 2015.

Leng, M. J. and Marshall, J. D.: Palaeoclimate interpretation of stable isotope data from lake sediment archives, Quaternary Sci. Rev., 23, 811-831, 2004.

Leng, M. J., Baneschi, I., Zanchetta, G., Jex, C. N., Wagner, B., and Vogel, H.: Late Quaternary palaeoenvironmental reconstruction from Lakes Ohrid and Prespa (Macedonia/Albania border) using stable isotopes, Biogeosciences, 7, 3109-3122, doi:10.5194/bg7-3109-2010, 2010a.

Leng, M. J., Jones, M. D., Frogley, M. R., Eastwood, W. J., Kendrick, C. P., and Roberts, C. N.: Detrital carbonate influences on bulk oxygen and carbon isotope composition of lacustrine sediments from the Mediterranean, Global Planet. Change, 71, 175-182, 2010b.

Leng, M. J., Wagner, B., Boehm, A., Panagiotopoulos, K., Vane, C. H., Snelling, A., Haidon, C., Woodley, E., Vogel, H., Zanchetta, G., and Baneschi, I.: Understanding past climatic and hydrological variability in the Mediterranean from Lake Prespa sediment isotope and geochemical record over the Last Glacial cycle, Quaternary Sci. Rev., 66, 123-136, 2013.

Lézine, A. M., von Grafenstein, U., Andersen, N., Belmecheri, S., Bordon, A., Caron, B., Cazet, J. P., Erlenkeuser, H., Fouache, E., Grenier, C., Huntsman-Mapila, P., Hureau-Mazaudier, D., Manelli, D., Mazaud, A., Robert, C., Sulpizio, R., Tiercelin, J. J., Zanchetta, G., and Zeqollari, Z.: Lake Ohrid, Albania, provides an exceptional multi-proxy record of environmental changes during the last glacial-interglacial cycle, Palaeogeogr. Palaeocl., 287, 116-127, 2010.

$\mathrm{Li}, \mathrm{H}$. C. and Ku, T. L.: $\delta^{13} \mathrm{C}-\delta^{18} \mathrm{O}$ covariance as a paleohydrological indicator for closed-basin lakes, Palaeogeogr. Palaeocl., 133, 69-80, 1997.

Linacre, E.: Climate Data and Resources: A Reference and Guide, Routledge, London, 1992.

Lindhorst, K., Krastel, S., Reicherter, K., Stipp, M., Wagner, B., and Schwenk, T.: Sedimentary and tectonic evolution of Lake Ohrid (Macedonia/Albania), Basin Res., 27, 84-101, 2015.

Lindhorst, K., Vogel, H., Krastel, S., Wagner, B., Hilgers, A., Zander, A., Schwenk, T., Wessels, M., and Daut, G.: Stratigraphic analysis of lake level fluctuations in Lake Ohrid: an integration of high resolution hydro-acoustic data and sediment cores, Biogeosciences, 7, 3531-3548, doi:10.5194/bg-7-3531-2010, 2010.

Lionello, P. (Ed.): The Climate of the Mediterranean Region, From the past to the future, Elsevier, London, 2012.

Lisiecki, L. E. and Raymo, M. E.: A Pliocene-Pleistocene stack of 57 globally distributed benthic $\delta^{18} \mathrm{O}$ records, Paleoceanography, 20, PA1003, doi:10.1029/2004PA001071, 2005.

Litt, T., Pickarski, N., Heumann, G., Stockhecke, M., and Tzedakis, P. C.: A 600,000 year long continental pollen record from Lake Van, eastern Anatolia (Turkey), Quaternary Sci. Rev., 104, 30 $41,2014$.

Loulergue, L., Schilt, A., Spahni, R., Masson-Delmotte, V., Blunier, T., Lemieux, B., Barnola, J. M., Raynaud, D., Stocker, T. F., and Chappellaz, J.: Orbital and millennial-scale features of atmospheric $\mathrm{CH}_{4}$ over the past 800,000 years, Nature, 453, 383-386, 2008.

Loutre, M. F. and Berger, A.: Marine Isotope Stage 11 as an analogue for the present interglacial, Global Planet. Change, 36, 209-217, 2003.

Ludvigson, G. A., González, L. A., Fowle, D. A., Roberts, J. A., Driese, S. G., Villarreal, M. A., Smith, J. J., and Suarez, M. B.: Paleoclimatic Applications and Modern Process Studies of Pedogenic Siderite, in: New Frontiers in Paleopedology and Terrestrial Paleoclimatology, SEPM (Society for Sedimentary Geology), 2013.

Lüthi, D., Le Floch, M., Bereiter, B., Blunier, T., Barnola, J. M., Siegenthaler, U., Raynaud, D., Jouzel, J., Fischer, H., Kawamura, K., and Stocker, T. F.: High-resolution carbon dioxide concentration record 650,000-800,000 years before present, Nature, 453, 379-382, 2008.

Maiorano, P., Tarantino, F., Marino, M., and De Lange, G. J.: Paleoenvironmental conditions at Core KC01B (Ionian Sea) through 
MIS 13-9: Evidence from calcareous nannofossil assemblages, Quatern. Int., 288, 97-111, 2013.

Martrat, B., Grimalt, J. O., Lopez-Martinez, C., Cacho, I., Sierro, F. J., Flores, J. A., Zahn, R., Canals, M., Curtis, J. H., and Hodell, D. A.: Abrupt temperature changes in the Western Mediterranean over the past 250,000 years, Science, 306, 1762-1765, 2004.

Martrat, B., Grimalt, J. O., Shackleton, N. J., De Abreu, L., Hutterli, M. A., and Stocker, T. F.: Four Climate Cycles of Recurring Deep and Surface Water Destabilizations on the Iberian Margin, Science, 27, 502-507, 2007.

Martrat, B., Jimenez-Amat, P., Zahn, R., and Grimalt, J. O.: Similarities and dissimilarities between the last two deglaciations and interglaciations in the North Atlantic region, Quaternary Sci. Rev., 99, 122-134, 2014.

Masson-Delmotte, V., Stenni, B., Pol, K., Braconnot, P., Cattani, O., Falourd, S., Kageyama, M., Jouzel, J., Landais, A., Minster, B., Barnola, J. M., Chappellaz, J., Krinner, G., Johnsen, S., Röthlisberger, R., Hansen, J., Mikolajewicz, U., and Otto-Bliesner, B.: EPICA Dome $\mathrm{C}$ record of glacial and interglacial intensities, Quaternary Sci. Rev., 29, 113-128, 2010.

Matter, M., Anselmetti, F. S., Jordanoska, B., Wagner, B., Wessels, M., and Wüest, A.: Carbonate sedimentation and effects of eutrophication observed at the Kališta subaquatic springs in Lake Ohrid (Macedonia), Biogeosciences, 7, 3755-3767, doi:10.5194/bg-7-3755-2010, 2010.

Matzinger, A., Jordanoski, M., Veljanoska-Sarafiloska, E., Sturm, M., Müller, B., and Wüest, A.: Is Lake Prespa Jeopardizing the Ecosystem of Ancient Lake Ohrid?, Hydrobiologia, 553, 89-109, $2006 \mathrm{a}$.

Matzinger, A., Spirkovski, Z., Patceva, S., and Wüest, A.: Sensitivity of Ancient Lake Ohrid to Local Anthropogenic Impacts and Global Warming, J. Great Lakes Res., 32, 158-179, 2006 b.

Matzinger, A., Schmid, M., Veljanoska-Sarafiloska, E., Patceva, S., Guseska, D., Wagner, B., Müller, B., Sturm, M., and Wüest, A.: Eutrophication of ancient Lake Ohrid: Global warming amplifies detrimental effects of increased nutrient inputs, Limnol. Oceanogr., 52, 338-353, 2007.

McKenzie, J. A.: Carbon isotopes and productivity in the lacustrine and marine environment, in: Chemical Processes in Lakes, edited by: Stumm, W., Wiley, New York, 1985.

Meyers, P. A. and Teranes, J. L.: Sediment Organic Matter, in: Tracking Environmental Change Using Lake Sediments, edited by: Last, W. M. and Smol, J. P., Developments in Paleoenvironmental Research, Springer, the Netherlands, 2001.

Mozley, P. S. and Wersin, P.: Isotopic composition of siderite as an indicator of depositional environment, Geology, 20, 817-820, 1992.

O’Neil, J. R., Clayton, R. N., and Mayeda, T. K.: Oxygen Isotope Fractionation in Divalent Metal Carbonates, J. Chem. Phys., 51, 5547-5558, 1969.

Panagiotopoulos, K., Aufgebauer, A., Schäbitz, F., and Wagner, B.: Vegetation and climate history of the Lake Prespa region since the Lateglacial, Quatern. Int., 293, 157-169, 2013.

Panagiotopoulos, K., Böhm, A., Leng, M. J., Wagner, B., and Schäbitz, F.: Climate variability over the last $92 \mathrm{ka}$ in SW Balkans from analysis of sediments from Lake Prespa, Clim. Past, 10, 643-660, doi:10.5194/cp-10-643-2014, 2014.

Paul, H. A., Bernasconi, S. M., Schmid, D. W., and McKenzie, J. A.: Oxygen isotope composition of the Mediterranean Sea since the
Last Glacial Maximum: Constraints from pore water analyses, Earth Planet. Sc. Lett., 192, 1-14, 2001.

Petit, J. R., Jouzel, J., Raynaud, D., Barkov, N. I., Barnola, J. M., Basile, I., Bender, M., Chappellaz, J., Davis, M., Delaygue, G., Delmotte, M., Kotlyakov, V. M., Legrand, M., Lipenkov, V. Y., Lorius, C., Pepin, L., Ritz, C., Saltzman, E., and Stievenard, M.: Climate and atmospheric history of the past 420,000 years from the Vostok ice core, Antarctica, Nature, 399, 429-436, 1999.

Pickarski, N., Kwiecien, O., Djamali, M., and Litt, T.: Vegetation and environmental changes during the last interglacial in eastern Anatolia (Turkey): a new high-resolution pollen record from Lake Van, Palaeogeogr. Palaeocl., 435, 145-158, 2015.

Piva, A., Asioli, A., Andersen, N., Grimalt, J. O., Schneider, R. R., and Trincardi, F.: Climatic cycles as expressed in sediments of the PROMESS1 borehole PRAD1-2, central Adriatic, for the last $370 \mathrm{ka}$ : 2. Paleoenvironmental evolution, Geochem. Geophy. Geosy., 9, Q03R02, doi:10.1029/2007GC001785, 2008.

Popovska, C. and Bonacci, O.: Basic data on the hydrology of Lakes Ohrid and Prespa, Hydrol. Process., 21, 658-664, 2007.

Prokopenko, A. A., Williams, D. F., Kuzmin, M. I., Karabanov, E. B., Khursevich, G. K., and Peck, J. A.: Muted climate variations in continental Siberia during the mid-Pleistocene epoch, Nature, 418, 65-68, 2002.

Prokopenko, A. A., Hinnov, L. A., Williams, D. F., and Kuzmin, M. I.: Orbital forcing of continental climate during the Pleistocene: a complete astronomically tuned climatic record from Lake Baikal, SE Siberia, Quaternary Sci. Rev., 25, 3431-3457, 2006.

Railsback, L. B., Gibbard, P. L., Head, M. J., Voarintsoa, N. R. G., and Toucanne, S.: An optimized scheme of lettered marine isotope substages for the last 1.0 million years, and the climatostratigraphic nature of isotope stages and substages, Quaternary Sci. Rev., 111, 94-106, 2015.

Regattieri, E., Zanchetta, G., Drysdale, R. N., Isola, I., Hellstrom, J. C., and Roncioni, A.: A continuous stable isotope record from the penultimate glacial maximum to the Last Interglacial (159$121 \mathrm{ka}$ ) from Tana Che Urla Cave (Apuan Alps, central Italy), Quaternary Res., 82, 450-461, 2014.

Regattieri, E., Giaccio, B., Zanchetta, G., Drysdale, R. N., Galli, P., Nomade, S., Peronace, E., and Wulf, S.: Hydrological variability over the Apennines during the Early Last Glacial precession minimum, as revealed by a stable isotope record from Sulmona basin, Central Italy, J. Quaternary Sci., 30, 19-31, 2015.

Regattieri, E., Giaccio, B., Galli, P., Nomade, S., Peronace, E., Messina P., Sposato, A., Boschi, C., and Gemelli, M.: A multiproxy record of MIS 11-12 deglaciation and glacial MIS 12 instability from the Sulmona Basin (central Italy), Quaternary Sci. Rev., 32, 129-145, 2016.

Ribolini, A., Isola, I., Zanchetta, G., Bini, M., and Sulpizio, R.: Glacial feature on the Galicica Mountains, Macedonia: preliminary report, Geogr. Fis. Din. Quat., 34, 247-255, 2011.

Roberts, N., Reed, J. M., Leng, M. J., Kuzucuoglu, C., Fontugne, M., Bertaux, J., Woldring, H., Bottema, S., Black, S., Hunt, E., and Karabiyikoglu, M.: The tempo of Holocene climatic change in the eastern Mediterranean region: New high-resolution craterlake sediment data from central Turkey, Holocene, 11, 721-736, 2001.

Roberts, N., Jones, M. D., Benkaddour, A., Eastwood, W. J., Filippi, M. L., Frogley, M. R., Lamb, H. F., Leng, M. J., Reed, J. M., Stein, M., Stevens, L., Valero-Garcés, B., and Zanchetta, G.: 
Stable isotope records of Late Quaternary climate and hydrology from Mediterranean lakes: the ISOMED synthesis, Quaternary Sci. Rev., 27, 2426-2441, 2008.

Rodrigues, T., Voelker, A. H. L., Grimalt, J. O., Abrantes, F., and Naughton, F.: Iberian Margin sea surface temperature during MIS 15 to 9 (580-300 ka): Glacial suborbital variability versus interglacial stability, Paleoceanography, 26, PA1204, doi:10.1029/2010PA001927, 2011.

Rosenbaum, J. and Sheppard, S. M. F.: An isotopic study of siderites, dolomites and ankerites at high temperatures, Geochim. Cosmochim. Ac., 50, 1147-1150, 1986.

Rossignol-Strick, M. and Paterne, M.: A synthetic pollen record of the eastern Mediterranean sapropels of the last $1 \mathrm{Ma}$ : implications for the time-scale and formation of sapropels, Mar. Geol., 153, 221-237, 1999.

Roucoux, K. H., Tzedakis, P. C., Frogley, M. R., Lawson, I. T., and Preece, R. C.: Vegetation history of the marine isotope stage 7 interglacial complex at Ioannina, NW Greece, Quaternary Sci. Rev., 27, 1378-1395, 2008.

Schrag, D. P., Adkins, J. F., McIntyre, K., Alexander, J. L., Hodell, D. A., Charles, C. D., and McManus, J. F.: The oxygen isotopic composition of seawater during the Last Glacial Maximum, Quaternary Sci. Rev., 21, 331-342, 2002.

Shackleton, N. J.: The 100,000-Year Ice-Age Cycle Identified and Found to Lag Temperature, Carbon Dioxide, and Orbital Eccentricity, Science, 289, 1897-1902, 2000.

Stankovic, S.: The Balkan Lake Ohrid and its Living World, Monographia Biologicae, Vol. IX, Uitgeverij Dr. W. Junk, Den Haag, 357 pp., 1960.

Stein, R., Hefter, J., Grützner, J., Voelker, A., and Naafs, B. D. A.: Variability of surface water characteristics and Heinrichlike events in the Pleistocene midlatitude North Atlantic Ocean: Biomarker and XRD records from IODP Site U1313 (MIS 169), Paleoceanography, 24, PA2203, doi:10.1029/2008PA001639, 2009.

Stevens, L. R., Wright Jr., H. E, and Ito, E.: Proposed changes in seasonality of climate during the Lateglacial and Holocene at Lake Zeribar, Iran, Holocene, 11, 747-755, 2001.

Sun, Y. and An, Z.: Late Pliocene-Pleistocene changes in mass accumulation rates of eolian deposits on the central Chinese Loess Plateau, J. Geophys. Res., 110, D23101, doi:10.1029/2005JD006064, 2005.

Talbot, M. R.: A review of the palaeohydrological interpretation of carbon and oxygen isotopic ratios in primary lacustrine carbonates, Chem. Geol., 80, 261-279, 1990.

Tzedakis, P. C., Andrieu, V., deBeaulieu, J. L., Crowhurst, S., Follieri, M., Hooghiemstra, H., Magri, D., Reille, M., Sadori, L., Shackleton, N. J., and Wijmstra, T. A.: Comparison of terrestrial and marine records of changing climate of the last 500,000 years, Earth Planet. Sc. Lett., 150, 171-176, 1997.

Tzedakis, P. C., Frogley, M. R., and Heaton, T. H. E.: Last Interglacial conditions in southern Europe: evidence from Ioannina, northwest Greece, Global Planet. Change, 36, 157-170, 2003a.

Tzedakis, P. C., McManus, J. F., Hooghiemstra, H., Oppo, D. W., and Wijmstra, T. A.: Comparison of changes in vegetation in northeast Greece with records of climate variability on orbital and suborbital frequencies over the last 450000 years, Earth Planet. Sc. Lett., 212, 197-212, 2003 b.
Tzedakis, P. C., Hooghiemstra, H., and Pälike, H.: The last 1.35 million years at Tenaghi Philippon: revised chronostratigraphy and long-term vegetation trends, Quaternary Sci. Rev., 25, 34163430, 2006.

Voelker, A. H. L., Rodrigues, T., Billups, K., Oppo, D., McManus, J., Stein, R., Hefter, J., and Grimalt, J. O.: Variations in midlatitude North Atlantic surface water properties during the midBrunhes (MIS 9-14) and their implications for the thermohaline circulation, Clim. Past, 6, 531-552, doi:10.5194/cp-6-531-2010, 2010.

Vogel, H., Wagner, B., Zanchetta, G., Sulpizio, R., and Rosén, P.: A paleoclimate record with tephrochronological age control for the last glacial-interglacial cycle from Lake Ohrid, Albania and Macedonia, J. Paleolimnol., 44, 295-310, 2010.

Wagner, B., Reicherter, K., Daut, G., Wessels, M., Matzinger, A., Schwalb, A., Spirkovski, Z., and Sanxhaku, M.: The potential of Lake Ohrid for long-term palaeoenvironmental reconstructions, Palaeogeogr. Palaeocl., 259, 341-356, 2008.

Wagner, B., Lotter, A. F., Nowaczyk, N., Reed, J. M., Schwalb, A., Sulpizio, R., Valsecchi, V., Wessels, M., and Zanchetta, G.: A 40,000-year record of environmental change from ancient Lake Ohrid (Albania and Macedonia), J. Paleolimnol., 41, 407-430, 2009.

Wagner, B., Vogel, H., Zanchetta, G., and Sulpizio, R.: Environmental change within the Balkan region during the past ca. $50 \mathrm{ka}$ recorded in the sediments from lakes Prespa and Ohrid, Biogeosciences, 7, 3187-3198, doi:10.5194/bg-7-3187-2010, 2010.

Wagner, B., Francke, A., Sulpizio, R., Zanchetta, G., Lindhorst, K., Krastel, S., Vogel, H., Rethemeyer, J., Daut, G., Grazhdani, A., Lushaj, B., and Trajanovski, S.: Possible earthquake trigger for 6th century mass wasting deposit at Lake Ohrid (Macedonia/Albania), Clim. Past, 8, 2069-2078, doi:10.5194/cp-8-20692012, 2012.

Wagner, B., Wilke, T., Krastel, S., Zanchetta, G., Sulpizio, R., Reicherter, K., Leng, M. J., Grazhdani, A., Trajanovski, S., Francke, A., Lindhorst, K., Levkov, Z., Cvetkoska, A., Reed, J. M., Zhang, X., Lacey, J. H., Wonik, T., Baumgarten, H., and Vogel, H.: The SCOPSCO drilling project recovers more than 1.2 million years of history from Lake Ohrid, Sci. Dril., 17, 19-29, doi:10.5194/sd-17-19-2014, 2014.

White, W. B.: The carbonate minerals, in: The infrared spectra of minerals, edited by: Farmer, V. C., Mineralogical Society Monograph, 4, Adlard \& Son, Dorking, Surrey, 1974.

Wick, L., Lemcke, G., and Sturm, M.: Evidence of Lateglacial and Holocene climatic change and human impact in eastern Anatolia: High-resolution pollen, charcoal, isotopic and geochemical records from the laminated sediments of Lake Van, Turkey, Holocene, 13, 665-675, 2003.

Wilson, G. P., Reed, J. M., Frogley, M. R., Hughes, P. D., and Tzedakis, P. C.: Reconciling diverse lacustrine and terrestrial system response to penultimate deglacial warming in southern Europe, Geology, 43, 819-822, 2015.

World Weather Information Service (WMO): Hong Kong Observatory, Hong Kong, 2015.

Yu, P.-S. and Chen, M.-T.: A prolonged warm and humid interval during marine isotope stage $13-15$ as revealed by hydrographic reconstructions from the South China Sea (IMAGES MD972142), J. Asian Earth Sci., 40, 1230-1237, 2011. 
Zanchetta, G., Borghini, A., Fallick, A. E., Bonadonna, F. P., and Leone, G.: Late Quaternary palaeohydrology of Lake Pergusa (Sicily, southern Italy) as inferred by stable isotopes of lacustrine carbonates, J. Paleolimnol., 38, 227-239, 2007.

Zhang, C. L., Horita, J., Cole, D. R., Zhou, J. Z., Lovley, D. R., and Phelps, T. J.: Temperature-dependent oxygen and carbon isotope fractionations of biogenic siderite, Geochim. Cosmochim. Ac., 65, 2257-2271, 2001.
Ziegler, M., Tuenter, E., and Lourens, L. J.: The precession phase of the boreal summer monsoon as viewed from the eastern Mediterranean (ODP Site 968), Quaternary Sci. Rev., 29, 1481-1490, 2010. 